\title{
\#USGS
}

-

Prepared in cooperation with the Bureau of Reclamation

\section{An Evaluation and Review of Water-Use Estimates and Flow Data for the Lower Klamath and Tule Lake National Wildlife Refuges, Oregon and California}

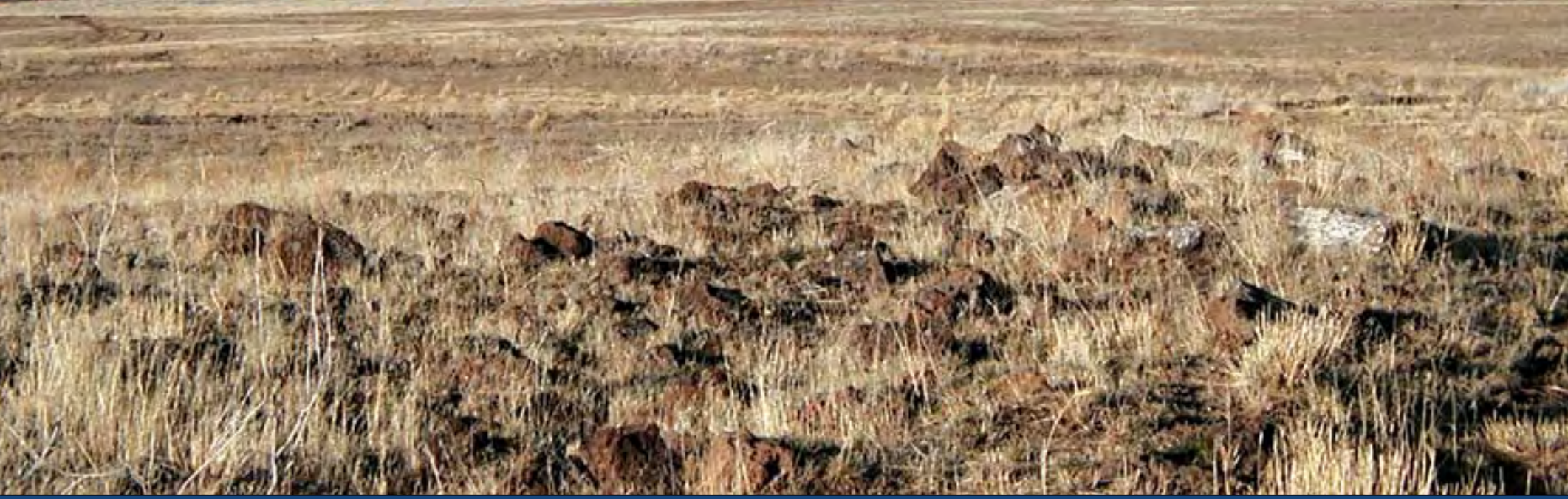

Scientific Investigations Report 2006-5036 
Cover: View north across the Lower Klamath Refuge looking towards the Klamath Hills and Swan Lake Point. (Photograph taken by Patrick C. Palmer, U.S. Geological Survey, 2001) 


\section{An Evaluation and Review of Water-Use Estimates and Flow Data for the Lower Klamath and Tule Lake National Wildlife Refuges, Oregon and California}

By John C. Risley and Marshall W. Gannett

Prepared in cooperation with the

Bureau of Reclamation

Scientific Investigations Report 2006-5036 


\section{U.S. Department of the Interior \\ P. Lynn Scarlett, Acting Secretary}

\section{U.S. Geological Survey \\ P. Patrick Leahy, Acting Director}

U.S. Geological Survey, Reston, Virginia: 2006

For sale by U.S. Geological Survey, Information Services
Box 25286, Denver Federal Center
Denver, CO 80225
For more information about the USGS and its products:
Telephone: 1-888-ASK-USGS
World Wide Web: http://www.usgs.gov/

Any use of trade, product, or firm names in this publication is for descriptive purposes only and does not imply endorsement by the U.S. Government.

Although this report is in the public domain, permission must be secured from the individual copyright owners to reproduce any copyrighted materials contained within this report.

Suggested citation:

Risley, J.C., and Gannett, M.W., 2006, An evaluation and review of water-use estimates and flow data for the Lower Klamath and Tule Lake National Wildlife Refuges, Oregon and California: U.S. Geological Survey Scientific Investigations Report 2006-5036, 18 p. 


\section{Contents}

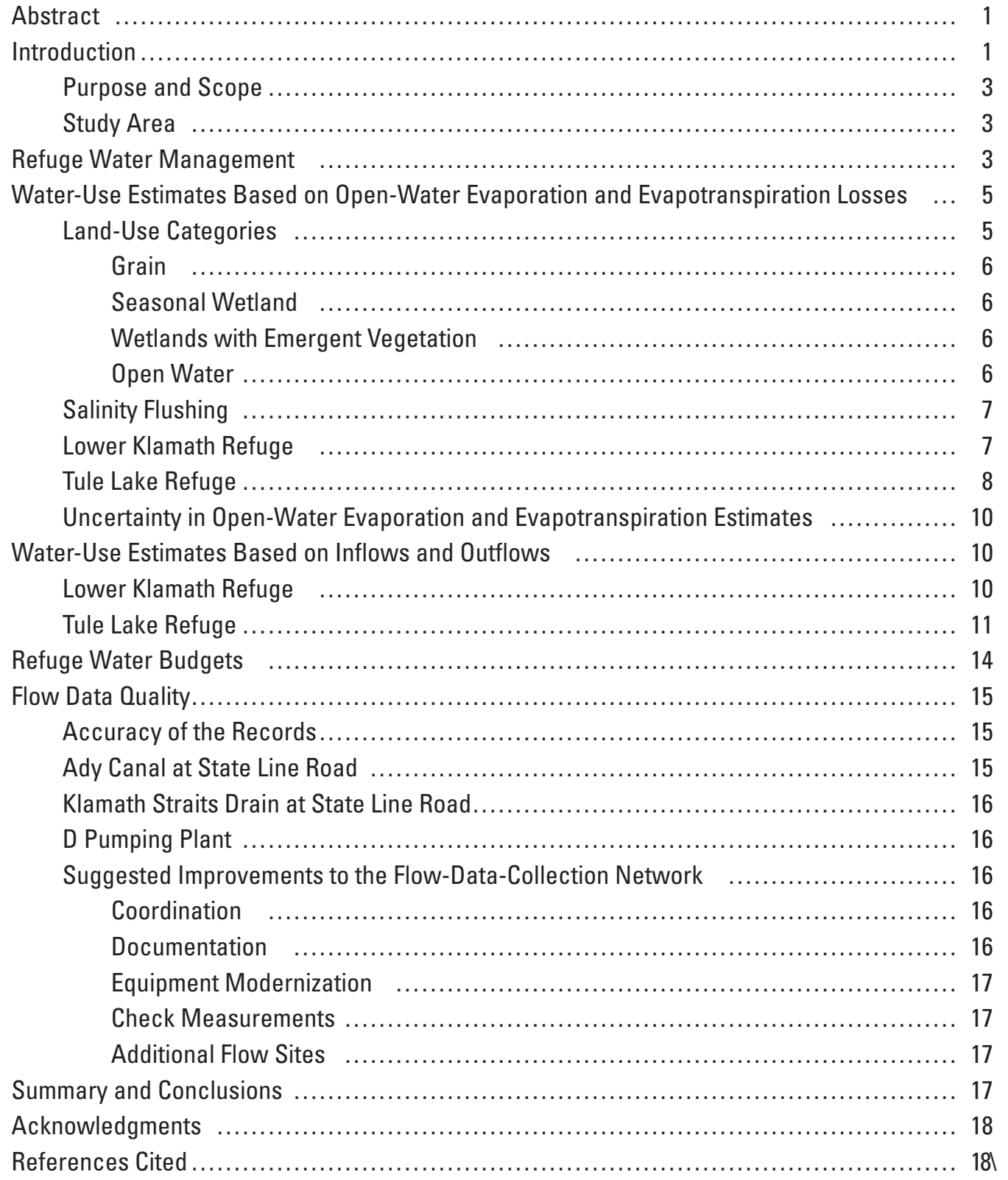




\section{Figures}

Figure 1. Map showing Lower Klamath and Tule Lake National Wildlife Refuges, Oregon and California

Figure 2. Diagram showing major flow paths entering and exiting the Lower Klamath and Tule Lake National Wildlife Refuges, Oregon and California

Figure 3. Graph showing Lower Klamath National Wildlife Refuge net inflow, Oregon and California, 1962-2005

Figure 4. Graphs showing monthly flows for Ady Canal, Klamath Straits Drain, and D Pumping Plant, Lower Klamath and Tule Lake National Wildlife Refuges, Oregon and California, 1961 through 2005

Figure 5. Diagram showing water budget, derived from an approximation of 2003-2005 conditions, for Lower Klamath and Tule Lake National Wildlife Refuges, Oregon and California

\section{Tables}

Table 1. Approximate water use by land-use category in the Lower Klamath and Tule Lake National Wildlife Refuges, Oregon and California

Table 2. Area of land in different land-use categories in the Lower Klamath National Wildlife Refuge, Oregon and California, 2003-2005

Table 3. Estimated water use in the Lower Klamath National Wildlife Refuge, Oregon and California, 2003-2005

Table 4. Area of land in different land-use categories in the Tule Lake National Wildlife Refuge, Oregon and California, 2003-2005

Table 5. Estimated water use in the Tule Lake National Wildlife Refuge, Oregon and California, 2003-2005

Table 6. Estimated 2003-2005 mean annual inflows to and outflows from the Lower Klamath and Tule Lake National Wildlife Refuges, Oregon and California

Table 7. Mean net inflows to the Lower Klamath National Wildlife Refuge, Oregon and California, 1962-2005 and 2003-2005

Table 8. Accuracy ratings for Ady Canal, Klamath Straits Drain, and D Pumping Plant flow records, Oregon and California..... 


\section{Conversion Factors and Datums}

Inch/Pound to SI

\begin{tabular}{lcl}
\hline Multiply & By & To obtain \\
\hline acre & 0.4047 & hectare \\
acre & 0.004047 & square kilometer \\
acre-foot per day (acre-ft/d) & 1,233 & cubic meter per day \\
acre-foot per year (acre-ft/yr) & 1,233 & cubic meter per year \\
acre-foot per year $(\mathrm{acre}-\mathrm{ft} / \mathrm{yr})$ & 0.001233 & cubic hectometer per year \\
cubic foot per second $\left(\mathrm{ft}^{3} / \mathrm{s}\right)$ & 0.02832 & cubic meter per second \\
gallon per minute $(\mathrm{gal} / \mathrm{min})$ & 0.06309 & liter per second \\
foot $(\mathrm{ft})$ & 0.3048 & meter \\
inch (in.) & 2.54 & centimeter \\
inch (in.) & 25.4 & millimeter \\
mile (mi) & 1.609 & kilometer \\
million gallons per day $(\mathrm{Mgal} / \mathrm{d})$ & 0.04381 & cubic meter per second \\
square mile $\left(\mathrm{mi}^{2}\right)$ & 2.590 & square kilometer \\
\hline
\end{tabular}

Temperature in degrees Celsius $\left({ }^{\circ} \mathrm{C}\right)$ may be converted to degrees Fahrenheit $\left({ }^{\circ} \mathrm{F}\right)$ as follows:

$$
{ }^{\circ} \mathrm{F}=\left(1.8 \times{ }^{\circ} \mathrm{C}\right)+32 \text {. }
$$

Datums

Vertical coordinate information is referenced to the National Geodetic Vertical Datum of 1929 (NGVD29).

Horizontal coordinate information is referenced to the North American Datum of 1927.

Elevation, as used in this report, refers to distance above the vertical datum. 
This page is intentionally left blank. 


\title{
An Evaluation and Review of Water-Use Estimates and Flow Data for the Lower Klamath and Tule Lake National Wildlife Refuges, Oregon and California
}

\author{
By John C. Risley and Marshall W. Gannett
}

\section{Abstract}

The Lower Klamath and Tule Lake National Wildlife Refuges, located in the upper Klamath Basin of Oregon and California, encompass approximately 46,700 and 39,100 acres, respectively. Demand for water in the semiarid upper Klamath Basin has increased in recent years, resulting in the need to better quantify water availability and use in the refuges. This report presents an evaluation of water-use estimates for both refuges derived on the basis of two approaches. One approach used evaporation and evapotranspiration estimates and the other used measured inflow and outflow data. The quality of the inflow and outflow data also was assessed.

Annual water use in the refuges, using evapotranspiration estimates, was computed with the use of different rates for each of four land-use categories. Annual water-use rates for grain fields, seasonal wetlands, permanently flooded wetlands with emergent vegetation, and open-water bodies were 2.5 , $2.9,2.63$, and 4.07 feet per year, respectively. Total water use was estimated as the sum of the products of each rate and the number of acres in its associated land-use category. Mean annual (2003-2005) water use for the Lower Klamath and Tule Lake refuges was approximately 124,000 and 95,900 acre-feet, respectively. To estimate water deliveries needed for each refuge, first, annual precipitation for 2003-2005 was subtracted from the annual water use for those years. Then, an adjusted total was obtained by adding 20 percent to the difference to account for salinity flushing. Resulting estimated mean annual adjusted needed water deliveries in 2003-2005 for the Lower Klamath and Tule Lake refuges were 107,000 and 82,800 acre-feet, respectively.

Mean annual net inflow to the refuges for 2003-2005 was computed by subtracting estimated and measured surfacewater outflows from inflows. Mean annual net inflow during the 3-year period for the Lower Klamath refuge, calculated for a subsection of the refuge, was approximately 73,700 acre-feet. The adjusted needed water delivery for this section of the refuge, calculated from evapotranspiration estimates, was approximately 77,600 acre-feet. For the Tule Lake refuge, mean annual net inflow during the 3-year period was approximately 76,100 acre-feet, which is comparable to the estimated annual needed water delivery for the refuge of 82,800 acre-feet.

For 1962-2005, mean annual net inflow to the Lower Klamath refuge was approximately 49,800 acre-feet, about 23,900 acre-feet less than for 2003-2005. Although mean April-September net inflows for 1962-2005 and 2003-2005 have remained fairly constant, annual net inflow has increased for October-March, which accounts for the difference. Consistently higher autumn and winter flow deliveries since the mid-1980s reflect a significant change in refuge management. More sections of the refuge are currently managed as seasonal wetlands than were in the 1960s and 1970s.

Flow records for the Ady Canal at State Line Road, Klamath Straits Drain at State Line Road, and D Pumping Plant were evaluated for their data quality. On the basis of USGS flow-record criteria, all three flow records were rated as "poor." By definition, 95 percent of the daily flows in a record having this rating could be in error by more than 15 percent.

\section{Introduction}

Increased pressure on water resources in the upper Klamath Basin of California and Oregon for wildlife, irrigation, and power generation has created a need to quantify water availability and use. Water supplied for habitat in wildlife refuges managed by the U.S. Fish and Wildlife Service (USFWS) constitutes a significant water use in the basin. The Bureau of Reclamation's (BOR) Klamath Project (Project) provides water to both the Lower Klamath and Tule Lake National Wildlife Refuges and also, at times, stores surplus water in the wildlife refuges to augment flow for habitat enhancement in the Klamath River. These refuges use water that is largely irrigation-return flow or runoff from springs and are at the lower, downgradient end of the Project, where excess water is ultimately pumped back into the Klamath River (fig. 1). 


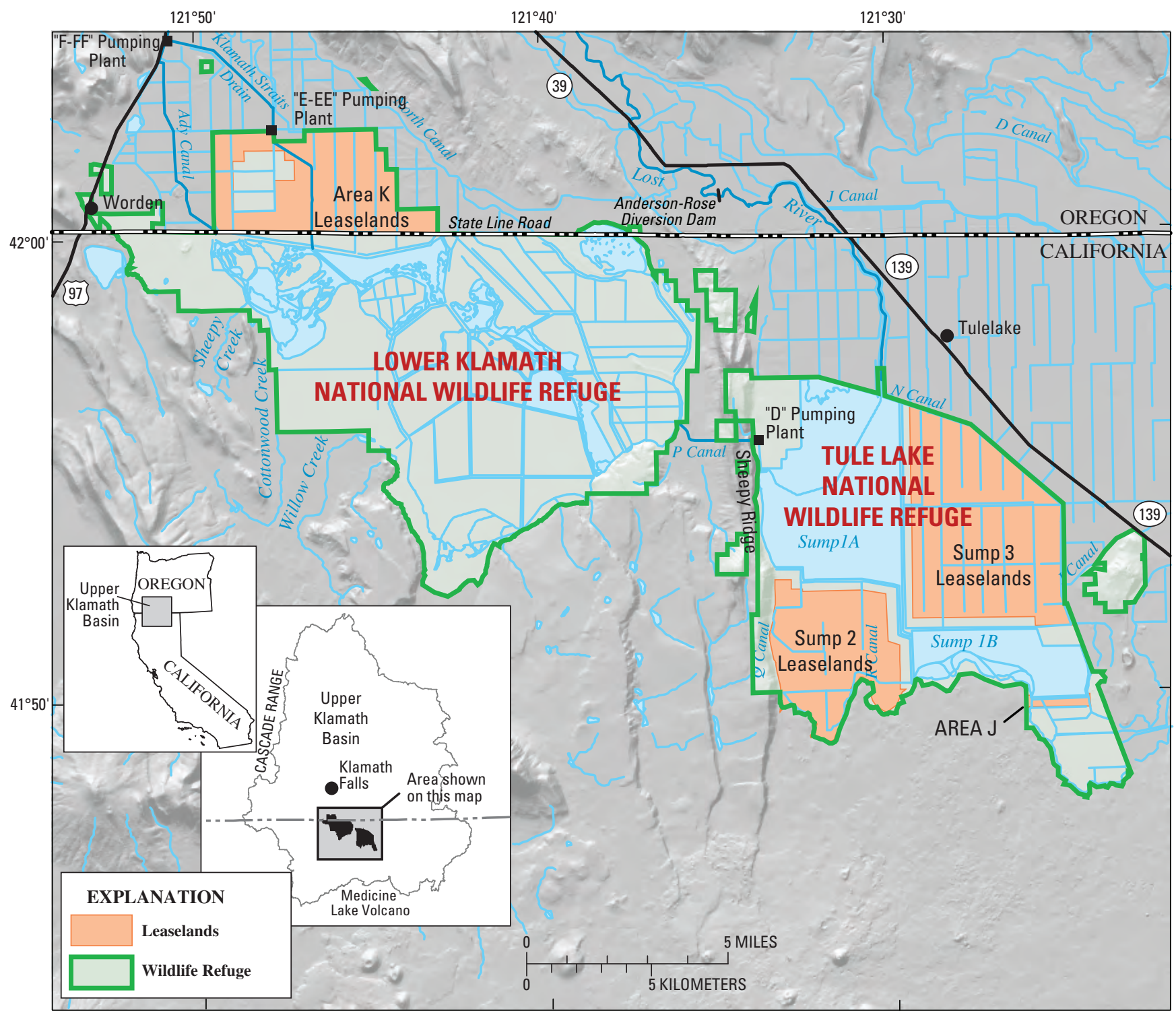

Base from U.S. Geological Survey digital data, 1:24,000 and 1:100,000 Universal Transverse Mercator projection, Zone 13.

Wildlife Refuge areas from U.S. Fish and Wildlife Service, 2001, 1:24,000 Datum is North American Datum of 1927 Irrigation boundaries from U.S. Bureau of Reclamation, 2004, 1:100,000

Figure 1. Lower Klamath and Tule Lake National Wildlife Refuges, Oregon and California.

As a result of the BOR's need to carefully manage water provided by the Project to all users, it is important to be able to assess its ability to estimate water use by the refuges with currently available information. In addition, the BOR also is interested in potential ways to improve measurement accuracy of the water delivered to and removed from the
Lower Klamath and Tule Lake National Wildlife Refuges to better quantify the overall Project agricultural and refuge water use. To this end, in 2005, the BOR asked the U.S. Geological Survey Oregon Water Science Center to evaluate water use and diversion and return-flow data in the Lower Klamath and Tule Lake National Wildlife Refuges. 


\section{Purpose and Scope}

The purpose of this report is to present the results of an assessment of the availability of inflow, outflow, open-waterevaporation, and vegetative-evapotranspiration data to estimate water use for the refuges and to provide an approximation of the error associated with the estimates. In the process of estimating water use for the refuges, a description of water routing and management, and therefore the water budget, was formulated and is described herein. A secondary goal of this assessment was to provide suggestions for improved data-collection methods and identify data-collection sites that would help reduce error in refuge water-use estimates.

The scope of this assessment and review was limited to the Lower Klamath and Tule Lake National Wildlife Refuges (fig. 1). The assessment included an analysis of:

- Evapotranspiration loss estimates,

- Inflows and outflows to and from the refuges (water budgets), and

- Data quality and general water-use estimation error.

Of specific interest was the comparison of measured and estimated water flows to and from the refuges and estimates of open-water-evaporation and evapotranspiration losses from areas of terrestrial and aquatic vegetation. Collection of additional data in the field was limited to a few check measurements of flow; significant data collection was outside the scope of this review. Much of the information evaluated in this review was obtained from the BOR's Klamath Basin Area Office and the USFWS.

\section{Study Area}

The study area is located near Klamath Falls in southern Oregon and northern California (fig. 1). The Lower Klamath and Tule Lake National Wildlife Refuges are two of six National Wildlife Refuges, managed by the USFWS in the upper Klamath Basin. Established by President Theodore Roosevelt in 1908, the Lower Klamath refuge is the oldest waterfowl refuge in the Nation. Composed of a mix of permanent and seasonal freshwater marshes, open water, grassy uplands, and croplands, it has a total area of approximately 46,700 acres. The refuge is intensively managed to provide feeding, resting, nesting, and brood-rearing habitat for waterfowl and other water birds. Approximately 10,000-12,000 acres of the refuge are leased or farmed cooperatively for cereal grain and alfalfa production. Waste grain, sometimes a set percentage of the harvest, is left on the fields each autumn, and becomes a major source of food for migrating and wintering waterfowl. The Tule Lake refuge was established in 1928 and encompasses approximately 39,100 acres of mostly open water and croplands. Approximately 17,000 acres of these lands are leased to farmers. The two refuges are adjacent to the southern edge of the Project. In total, the two refuges and the Project encompass approximately 240,000 acres.

Prior to agricultural development, the Klamath Basin had approximately 185,000 acres of shallow lakes and freshwater marshes (U.S. Fish and Wildlife Service, 2005). A large wetland marsh and lake covered the region between the Klamath River and the present day Lower Klamath National Wildlife Refuge. Tule Lake was the terminus of the closed Lost River Basin. Unlike other closed basin lakes, Tule Lake was not saline probably because of lake discharge to the ground-water system to the south, allowing circulation through the lake and thus preventing the accumulation of salts and deposition of evaporites.

Beginning in 1905 and continuing through the 1950s, much of the Lower Klamath and Tule Lake wetlands were drained for agricultural development. Today, less than 25 percent of the original wetlands remain (U.S. Fish and Wildlife Service, 2005).

The Tule Lake and Lower Klamath Lake refuges occupy sediment-filled structural basins east of the Cascade Range and north of Medicine Lake Volcano. The downfaulted basins are surrounded by faulted Tertiary and Quaternary volcanic rocks and Tertiary lacustrine deposits (Gay and Aune, 1958). The two refuges are separated by a linear, north-south trending upland with prominent fault escarpments known as Sheepy Ridge, which is composed of Tertiary volcanic and sedimentary deposits. The basin-filling sediment consists of fine-grained lacustrine deposits ranging in age from late Tertiary to Quaternary (Rieck and others, 1992).

\section{Refuge Water Management}

With the development of the Project in the early 1900s, the Lower Klamath and Tule Lake National Wildlife Refuges have become highly regulated systems. Water enters the two refuges by a variety of pathways, which include precipitation, natural runoff, ground-water seepage, pipes, and irrigation canals. Water leaves the refuges through open-water evaporation, evapotranspiration, drainage canals, and groundwater seepage (fig. 2). 


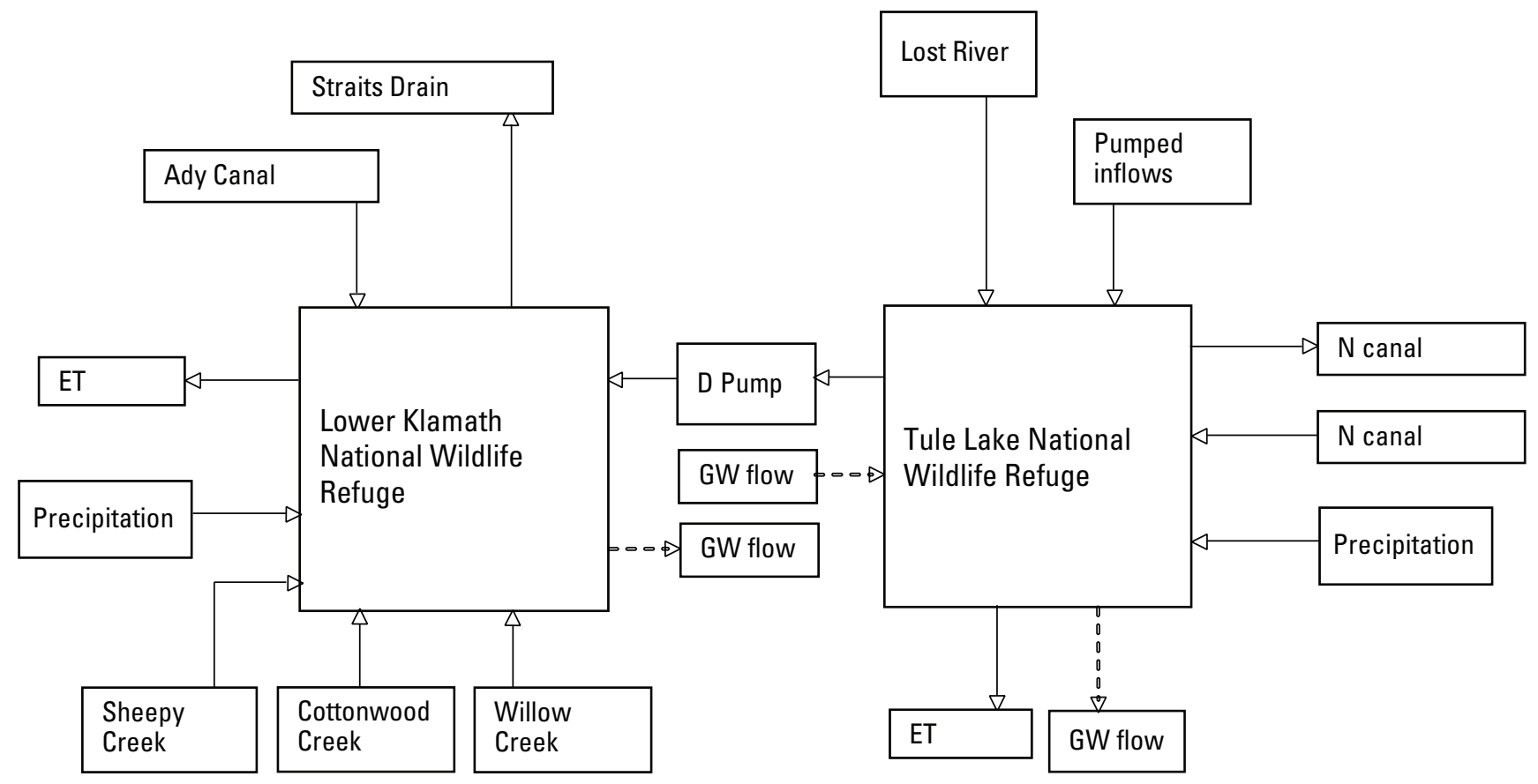

Figure 2. Major flow paths entering and exiting the Lower Klamath and Tule Lake National Wildlife Refuges, Oregon and California.

Project water enters the Lower Klamath refuge through the Ady Canal and through the D Pumping Plant. Natural surface-water flow enters the refuge from Sheepy, Cottonwood, and Willow Creeks. Combined mean annual flow from these three creeks is approximately $30 \mathrm{ft}^{3} / \mathrm{s}$ on the basis of miscellaneous flow measurements made throughout water year 1955 (Wood, 1960). However, these flows have decreased because of ground-water pumping on private lands outside of the refuge within the last 50 years. Flow from the D Pumping Plant enters the Lower Klamath refuge via the P Canal, located on the eastern boundary of the refuge. P Canal flows, along with flows from the Ady Canal, are used to flood 40-50 refuge units. Units are defined land areas within the refuges that are managed for a specific purpose and in a specific way. For example, some units are permanently flooded wetlands, whereas other units are flooded seasonally. Seasonally flooded units typically are filled in the autumn and drained during the following spring or summer. Other units are leased to private farmers and used for grain or hay production. Although most of the Lower Klamath refuge is located south of State Line Road (California Hwy 161) in California, a portion of the refuge, known as the Area $\mathrm{K}$ Lease Lands, is located on the northern side of the State Line Road. Those units are leased to private farmers for grain production. In addition to openwater evaporation, evapotranspiration from areas of terrestrial or aquatic vegetation, and ground-water seepage, water also leaves the refuge northward through the Klamath Straits Drain. From the refuge, flow in the drain is pumped through the E-EE and F-FF Pumping Plants to the Klamath River.
The Tule Lake refuge comprises four major sumps: Sump 1A, Sump 1B, Sump 2, and Sump 3 (fig. 1). Sump 1A is a permanent open-water body with a minimum and maximum water elevation of 4,034 and 4,035.5 ft above NGVD29, respectively. The minimum elevation is maintained under Endangered Species Act (ESA) guidelines for Lost River and shortnose sucker habitat protection. One source of water entering Sump 1A is the Lost River, which is regulated by the Anderson-Rose Diversion Dam. Flow also is pumped into Sump 1A from drainage canals in the Tulelake Irrigation District (TID) close to the refuge boundary of the sump. TID return flows also enter the sump through shallow groundwater seepage in this same area. Additional surface-water flow enters Sump 1A via the N Canal, which is located along the eastern and northeastern boundary of the refuge. When water in Sump 1A rises above the maximum elevation, it is pumped to the Lower Klamath refuge via the D Pumping Plant and through a tunnel under Sheepy Ridge. Water also is sent to the Lower Klamath refuge at other times when deliveries are requested by refuge managers. Smaller water volumes from Sump 1A also are used as water supply for agriculture and wildlife habitat needs in the adjoining Sumps 2 and 3. Sump 1B is hydrologically connected to Sump 1A through a narrow, gated canal. For many years, Sump 1B was managed as a permanent open-water body. However, in recent years Sump $1 \mathrm{~B}$ has been managed as either a year-round water body or sometimes a seasonal wetland through regulation of the flow in the canal separating the two sumps. 
Almost all of the Sump 2 and 3 lands are leased to private farmers for grain production. However, approximately 5-10 percent of the units in these two sumps are rotated every year between grain production, permanent flooding (an entire year), and seasonal flooding. Sump 2 receives water from Sumps 1A and $1 \mathrm{~B}$ through the Q and R Canals. Drainage water from Sump 2 is pumped back into Sump 1A. Most water for Sump 3 is delivered through the N Canal. A smaller volume of water for Sump 3 comes from Sump 1A. Drainage water is pumped out of Sump 3 back into the N Canal and Sumps 1A and 1B.

To improve their understanding of water management for the Tule Lake refuge, the USFWS developed a surfacewater budget for the refuge (Tim Mayer, U.S. Fish and Wildlife Service, Portland, Oregon, written commun., 2005). Data used in the budget analysis were based on pump flow records and miscellaneous surface-water stream and canal flow measurements made by the BOR, USFWS, and Tulelake Irrigation District from 1988 to 1998 . Because of limited available documentation regarding data from these agencies, it is acknowledged that potential error could be significant. By USGS surface-water flow measurement standards, these data would be rated as "poor," with errors greater than 15 percent.

The USFWS surface water-budget analysis for Sumps $1 \mathrm{~A}$ and $1 \mathrm{~B}$ had a residual of approximately $-30,300$ acre-ft/yr $\left(-41.8 \mathrm{ft}^{3} / \mathrm{s}\right)$, Sump 2 had a residual close to zero, and Sump 3 had a residual of approximately 11,300 acre-ft/yr (15.6 $\left.\mathrm{ft}^{3} / \mathrm{s}\right)$. For the entire Tule Lake refuge, there was a net surfacewater flow residual of $-19,000$ acre- $\mathrm{ft} / \mathrm{yr}\left(26.2 \mathrm{ft}^{3} / \mathrm{s}\right)$. These residuals, or differences between surface-water inflow and outflow, are the result of both surface-water flow measurement error and probable unmeasured ground-water inflow and outflow. For each residual, the proportion attributed to surfacewater measurement error versus the proportion attributed to ground-water flow is unknown. Possible ground-water inflow and outflow suggested by the residuals in the USFWS surface-water budget analysis is consistent with the general northwestern to southeastern ground-water flow direction for the region surrounding the refuge. On average, the groundwater table of the Lower Klamath refuge is approximately 50-60 ft higher than the Tule Lake refuge. As a result, there is a significant ground-water gradient underneath Sheepy Ridge, which indicates potential ground-water flow from Lower Klamath refuge into Sump 1A. Although not confirmed, it is possible that there is ground-water discharge through diffuse seepage or submerged springs into Sump 1A near the base of Sheepy Ridge. For Sump 3, it is possible that the surplus water leaves the sump through seepage into the ground-water system. Because the entire Tule Lake refuge was once a natural lake, the construction of deep drainage canals in Sump 3 may have increased seepage rates by penetrating through the less permeable sedimentary soil layers near the surface.

\section{Water-Use Estimates Based on Open-Water Evaporation and Evapotranspiration Losses}

As part of this assessment, open-water evaporation and evapotranspiration losses from areas of emergent and terrestrial vegetation in the refuges were quantified for the purpose of comparison with measured inflows and outflows to and from the refuges. This comparison allowed the estimation of water use in the refuges by two different methods.

Although more than 90 percent of the land area of the two refuges is supplied in some way by Project water, a few upland units and some small land parcels, which are separate from the main bodies of the refuges, were not included in this assessment because they do not receive Project water.

\section{Land-Use Categories}

An estimation of total water use in the refuges was made by summing water use from four land-use categories: grain, seasonal wetland, permanently flooded wetland with emergent vegetation, and open water. Approximate monthly and annual water-use rates for the land-use categories, derived from recent studies by the USFWS and Burt and Freeman (2003), are shown in table 1 . These rates are multiplied by total acreage of the land-use categories to derive total water-use volumes.

Table 1. Approximate water use by land-use category in the Lower Klamath and Tule Lake National Wildlife Refuges, Oregon and California.

[Values are in feet. Sources: Burt and Freeman, 2003; Tim Mayer, U.S. Fish and Wildlife Service, Portland, Oregon, written commun., 2005. -, no data]

\begin{tabular}{lcccccccccccccc}
\hline \multicolumn{1}{c}{ Category } & Jan. & Feb. & Mar. & Apr. & May & June & July & Aug. & Sept. & Oct. & Nov. & Dec. & Apr.-0ct. & Annual \\
\hline Grain & 0.034 & 0.066 & 0.138 & 0.201 & 0.323 & 0.417 & 0.448 & 0.370 & 0.262 & 0.154 & 0.056 & 0.032 & 2.18 & 2.50 \\
Seasonal wetland & - & - & - & - & - & - & - & - & .967 & .967 & .967 & - & - & 2.90 \\
Emergent vegetation & .014 & .040 & .122 & .188 & .270 & .394 & .567 & .485 & .324 & .179 & .030 & .014 & 2.41 & 2.63 \\
Open water & .060 & .094 & .201 & .342 & .566 & .629 & .714 & .640 & .510 & .262 & .000 & .048 & 3.66 & 4.07 \\
\hline
\end{tabular}




\section{Grain}

Approximately 55 percent of Tule Lake and 27 percent of Lower Klamath refuge land areas are dedicated to grain production. The USFWS estimated that $2.5 \mathrm{ft} / \mathrm{yr}$ was an approximate value of water use for grain production lands (Tim Mayer, U.S. Fish and Wildlife Service, Portland, Oregon, written commun., 2005). This estimate was based on data in the State of Oregon's hydrology report for the Klamath Basin (Oregon Water Resources Department, 1971), local irrigation district delivery guidelines, and the USFWS assessment of water delivery needs for marsh vegetation. Burt and Freeman (2003) also made estimates of annual evapotranspiration for 1999, 2000, and 2001 for barley, oats, and wheat that ranged from 2.22 to $2.64 \mathrm{ft}$ for the Tule Lake and Lower Klamath refuge areas. On the basis of these studies, $2.5 \mathrm{ft} / \mathrm{yr}$ was selected as an appropriate annual water-use rate for grain production areas. Mean monthly reference evapotranspiration rates estimated for the Klamath Falls BOR AgriMet station (KFLO), located approximately 15-20 mi north of the refuges, were used to partition the annual grain water use into monthly rates, as shown in table 1 (Bureau of Reclamation, 2004).

\section{Seasonal Wetland}

Roughly half of the Lower Klamath refuge and 5 percent of the Tule Lake refuge contain seasonal wetlands, which are flooded (sometimes referred to as "floodup") generally during the autumn (September-November). They are dewatered in the late spring and early summer through a combination of drainage and evaporation. Each seasonal-wetland unit has a target water level associated with it. During the autumn floodup, when sufficient water deliveries are sent to the refuges, water levels are manipulated in each unit until the target level is reached (Tim Mayer, U.S. Fish and Wildlife Service, Portland, Oregon, written commun., 2005). Mayer and Thomasson (2004) measured the volume of water needed to fill three representative seasonal-wetland units in the Lower Klamath refuge. In their study, this volume of water was also partitioned into soil saturation requirements, surfacewater volume, and evapotranspiration losses. On average, the floodup volume for the units was $2.90 \mathrm{ft}$ from SeptemberNovember (table 1). Of this amount, about one-half $(1.5 \mathrm{ft})$ is used to saturate the soils, and roughly $0.5 \mathrm{ft}$ is lost through evaporation and evapotranspiration during October-April. In late spring, the remaining $0.9 \mathrm{ft}$ of delivered floodup water, plus approximately $0.9 \mathrm{ft}$ of accumulated precipitation that falls between October and April, is drained from the seasonal units and leaves the refuges.

\section{Wetlands with Emergent Vegetation}

Permanent (year-round) wetland units encompass approximately 23 percent of the Lower Klamath refuge and 40 percent of the Tule Lake refuge. Two rates were used to estimate water use in these units. The emergent-vegetation water-use rate was applied to the vegetation-dominated portion of each unit. The open-water evaporation rate (described below) was applied to the open-water portions.

The rate of water use by emergent vegetation was estimated using a USFWS model based on the PriestlyTaylor evapotranspiration equation, which uses minimum and maximum daily air temperatures as input (Ronald R. Thomasson, U.S. Fish and Wildlife Service, Portland, Oregon, written commun., 2005). The model was calibrated using measured field data from energy budget studies made at several locations in the Klamath National Wildlife Refuges (W.R. Bidlake and K. Payne, U.S. Geological Survey, written commun., 1998). Using a simulation period of 1961-1990, the model predicted a median April-October total evapotranspiration loss of $2.41 \mathrm{ft}$. This value and monthly reference evapotranspiration rates estimated for the Klamath Falls BOR AgriMet station (KFLO) were used to estimate evapotranspiration losses for the months of November through March (Bureau of Reclamation, 2004). The annual evapotranspiration rate for the emergent vegetation category was then estimated to be $2.63 \mathrm{ft}$ (table 1).

\section{Open Water}

Pan evaporation data from the Tule Lake Agricultural Station were used to estimate evaporation from open-water portions of the permanent wetlands. The data were from April through October 1956-1981. Average total April-October pan evaporation for the period of record was $4.08 \mathrm{ft}$. Because the open-water areas on the refuges are small and shallow, a pan evaporation coefficient of 0.9 was used (Dunne and Leopold, 1978). This produced a mean April-October open-water evaporation rate of $3.66 \mathrm{ft}$, as shown in table 1 . Year-round monthly pan evaporation data collected at the Klamath Falls Agricultural Station (located farther away from the refuges than the Tule Lake Agricultural Station) were used to estimate open-water evaporation for the months of November through March. On average, the Tule Lake pan evaporation rates are 95 percent of the Klamath Falls pan evaporation rates due to climatic differences. Therefore, mean November-March Klamath Falls pan evaporation data were simply multiplied by 0.95 to estimate Tule Lake pan evaporation data for those months. Those estimates were then adjusted further by using a 0.9 pan evaporation coefficient to estimate open-water evaporation. The mean annual rate for open-water evaporation was estimated to be $4.07 \mathrm{ft}$ (table 1). 


\section{Salinity Flushing}

In addition to estimating evapotranspiration losses, it also is necessary to account for the additional water in the refuge units needed to prevent salinity accumulation over time. Specific conductance data collected at irregular intervals by both the BOR and USGS at various inflow and outflow locations near the refuges from the early 1990s to the present show that specific conductance levels have remained relatively constant over time (MacCoy, 1994; Cindy Williams, Bureau of Reclamation, written commun., 2005). The volume of additional water needed to avoid exceeding a maximum salinity level for flows leaving a water body can be estimated by multiplying the net evapotranspiration times a salinity factor. Net evapotranspiration is estimated as evapotranspiration minus precipitation. The salinity factor is estimated as the maximum outflow specific conductance level divided by the difference between outflow specific conductance and measured inflow specific conductance.

The Lost River is a major point of inflow for the Tule Lake refuge. Specific conductance data collected on the Lost River at State Line Road has a mean of approximately 0.5 millisiemens per centimeter. To prevent outflow specific conductance from exceeding 3.0 millisiemens per centimeter, a salinity factor of 1.2 would be needed. For the Lower Klamath refuge, mean inflow specific conductance for the Ady Canal at State Line Road and Pumping Plant D is 0.14 and 0.60 millisiemens per centimeter, respectively. Salinity factors based on these specific conductance levels were computed as 1.16 and 1.25 , respectively. On the basis of these calculations, an overall salinity factor of 1.20 (20 percent of the net evapotranspiration) seemed reasonable to apply to both refuges. The U.S. Fish and Wildlife Service also estimated a salinity factor of 1.20 for both refuges in their analyses (Tim Mayer, U.S. Fish and Wildlife Service, Portland, Oregon, written commun., 2005).

\section{Lower Klamath Refuge}

The Lower Klamath refuge is divided into approximately 50 land-use units. A breakdown of the cumulative acres by area and land-use category for 2003, 2004, and 2005 is shown in table 2. Acreage data for each land-use category are from the annual USFWS habitat plans for the refuge. However, the total number of acres shown in table 2 does not include all of the Lower Klamath refuge. Some small, noncontiguous units and nonirrigated upland areas are not included because precise data for both refuges was not easily obtainable. However, the
Table 2. Area of land in different land-use categories in the Lower Klamath National Wildlife Refuge, Oregon and California, 2003-2005.

[Project, lands south of State Line Road irrigated by Bureau of Reclamation Project; Area K, Area K leased lands and all other units north of State Line Road; Non-Project, lands south of State Line Road not irrigated with Project water. Some small units of refuge property near the boundaries were not included. Source: Tim Mayer, U.S. Fish and Wildlife Service, Portland, Oregon, written commun., 2005]

\begin{tabular}{|c|c|c|c|c|}
\hline \multirow{2}{*}{ Land-use category } & \multicolumn{4}{|c|}{ Area (acres) } \\
\hline & Project & Area K & Non-project & Total \\
\hline \multicolumn{5}{|c|}{2003 Habitat Plan } \\
\hline Grain & 3,611 & 6,391 & 0 & 10,002 \\
\hline Seasonal wetland & 14,992 & 207 & 7,718 & 22,917 \\
\hline Emergent vegetation & 5,399 & 0 & 0 & 5,399 \\
\hline Open water & 4,492 & 0 & 0 & 4,492 \\
\hline Total & 28,494 & 6,598 & 7,718 & 42,810 \\
\hline \multicolumn{5}{|c|}{2004 Habitat Plan } \\
\hline Grain & 6,304 & 6,391 & 0 & 12,695 \\
\hline Seasonal wetland & 15,851 & 207 & 5,671 & 21,729 \\
\hline Emergent vegetation & 5,399 & 0 & 0 & 5,399 \\
\hline Open water & 4,492 & 0 & 0 & 4,492 \\
\hline Total & 32,046 & 6,598 & 5,671 & 44,315 \\
\hline \multicolumn{5}{|c|}{2005 Habitat Plan } \\
\hline Grain & 5,135 & 6,352 & 0 & 11,488 \\
\hline Seasonal wetland & 14,213 & 179 & 5,329 & 19,721 \\
\hline Emergent vegetation & 5,899 & 0 & 0 & 5,899 \\
\hline Open water & 4,480 & 0 & 0 & 4,480 \\
\hline Total & 29,727 & 6,532 & 5,329 & 41,588 \\
\hline
\end{tabular}

table does show totals for essentially all units that typically are irrigated for a particular land use. Approximately 35,000 acres, most of the refuge, is located in California south of State Line Road. With the exception of approximately 5,000-7,000 acres, most of this area is irrigated by Project water. Some units that are not irrigated with Project water are irrigated with natural surface-water runoff from Sheepy, Cottonwood, and Willow Creeks and ground-water discharge. An additional 6,600 acres of the refuge are located north of State Line Road. Known as the Area K Lease Lands, these units are leased to farmers on an annual basis for grain production and are irrigated with Project water. The water for these units comes from the Ady Canal at various diversion points upstream of the Ady Canal flow gage on State Line Road. 
The main area of the refuge, south of State Line Road, contains a mix of land-use categories. Most of these units are managed as seasonal wetlands. However, some units are permanent open-water wetlands, and other units are leased for grain production. With the exception of permanent openwater units, many units in the refuge change from one land use to another on an annual basis. Table 3 shows water-use estimates for the Lower Klamath refuge derived by using

Table 3. Estimated water use in the Lower Klamath National Wildlife Refuge, Oregon and California, 2003-2005.

[Project, lands south of State Line Road irrigated by Bureau of Reclamation Project; Area K, Area K leased lands and all other units north of State Line Road; Non-Project, lands south of State Line Road not irrigated with Project water. Water-use categories are based on annual rates in table 1. Adjusted water delivery is the estimated water delivery plus additional water for salinity flushing. Source: Tim Mayer, U.S. Fish and Wildlife Service, Portland, Oregon, written commun., 2005]

\begin{tabular}{|c|c|c|c|c|}
\hline \multirow{2}{*}{ Land-use category } & \multicolumn{4}{|c|}{ Water use (acre-feet) } \\
\hline & Project & Area K & Non-project & Total \\
\hline \multicolumn{5}{|c|}{2003 Habitat Plan } \\
\hline Grain & 9,028 & 15,979 & 0 & 25,008 \\
\hline Seasonal wetland & 43,477 & 600 & 22,382 & 66,459 \\
\hline Emergent vegetation & 14,182 & 0 & 0 & 14,182 \\
\hline Open water & 18,260 & 0 & 0 & 18,260 \\
\hline Total water use & 84,947 & 16,580 & 22,382 & 123,909 \\
\hline Precipitation & $-24,030$ & $-5,564$ & $-6,509$ & $-36,103$ \\
\hline Water delivery & 60,917 & 11,015 & 15,873 & 87,806 \\
\hline Total & 73,101 & 13,218 & 19,048 & 105,367 \\
\hline \multicolumn{5}{|c|}{2004 Habitat Plan } \\
\hline Grain & 15,760 & 15,978 & 0 & 31,738 \\
\hline Seasonal wetland & 45,968 & 600 & 16,446 & 63,014 \\
\hline Emergent vegetation & 14,201 & 0 & 0 & 14,201 \\
\hline Open water & 18,281 & 0 & 0 & 18,281 \\
\hline Total water use & 94,209 & 16,578 & 16,446 & 127,233 \\
\hline Precipitation & $-22,486$ & $-4,630$ & $-3,979$ & $-31,094$ \\
\hline Water delivery & 71,723 & 11,948 & 12,467 & 96,138 \\
\hline Total & 86,068 & 14,338 & 14,960 & 115,366 \\
\hline \multicolumn{5}{|c|}{2005 Habitat Plan } \\
\hline Grain & 12,835 & 15,881 & 0 & 28,716 \\
\hline Seasonal wetland & 41,218 & 520 & 15,452 & 57,190 \\
\hline Emergent vegetation & 15,516 & 0 & 0 & 15,516 \\
\hline Open water & 18,232 & 0 & 0 & 18,232 \\
\hline Total water use & 87,800 & 16,401 & 15,452 & 119,654 \\
\hline Precipitation & $-26,333$ & $-5,786$ & $-4,721$ & $-36,840$ \\
\hline Water delivery & 61,467 & 10,615 & 10,732 & 82,814 \\
\hline Total & 73,761 & 12,738 & 12,878 & 99,377 \\
\hline \multicolumn{5}{|c|}{2005 Habitat Plan } \\
\hline Total water use & 88,986 & 16,520 & 18,093 & 123,599 \\
\hline $\begin{array}{l}\text { Adjusted water } \\
\text { delivery }\end{array}$ & 77,643 & 13,431 & 15,629 & 106,703 \\
\hline
\end{tabular}

annual evapotranspiration and evaporation rates for grain, seasonal wetland, emergent vegetation, and open water shown in table 1. For the largest open-water permanent wetland unit (Unit 2), the emergent vegetation evapotranspiration rate was applied to 83 percent of the area, and the open-water evaporation rate was applied to the remaining 17 percent. A mixture of other emergent vegetation and open-water ratios were applied to the other permanent wetland units (Tim Mayer, U.S. Fish and Wildlife Service, Portland, Oregon, written commun., 2005).

The mean annual water use for the entire Lower Klamath refuge for 2003-2005 (including seasonal-wetland water use) was approximately 124,000 acre-ft (table 3). This volume includes water use in all units served by Project water on both sides of State Line Road plus approximately 5,000-7,000 acres of land not served by Project water. However, the 3-year mean annual water use for refuge lands south of State Line Road, which are served by the Project water deliveries, was approximately 89,000 acre-ft.

To estimate needed annual water deliveries for the refuge, estimated annual water use was reduced by annual precipitation and adjusted for salinity flushing. For water years 2003, 2004, and 2005, annual precipitation, measured nearby at the BOR AgriMet station in Worden, Oregon (WRDO), near the northwestern corner of the refuge, was 10.1, 8.4, and 10.6 in., respectively (Bureau of Reclamation, 2004). Needed annual water deliveries for each of the three main refuge lands (Project, Area K, non-Project) are shown in table 3 . The needed mean annual water delivery for the entire refuge for the 3 -year period was estimated to be 107,000 acre-ft.

\section{Tule Lake Refuge}

The total number of acres by sump and by land-use category for the Tule Lake refuge for 2003, 2004, and 2005 are shown in table 4. Because the cumulative size of each land-use category continually changes, a better representation of recent conditions can be made using the last 3 years of data instead of just 2005. Acreage data for each of the land-use categories are from the annual USFWS habitat plans for the refuge. The total number of acres each year for each sump and the sum of all the sumps are not necessarily the same each year. Differences can be attributed to mapping error or to small units that were included or not included in the habitat plan for a given year. The total number of acres shown also does not include all refuge property. Small, noncontiguous units; the Area J unit; and narrow upland strips located along the borders of Sumps 1A, 1B, and 2 were not included because they do not receive Project water.

Sump 1A was managed as a permanent wetland in all 3 years. Approximately 10 percent of the unit was defined as emergent vegetation and the remaining 90 percent as open water (Tim Mayer, U.S. Fish and Wildlife Service, Portland, Oregon, oral commun., 2005). To estimate water use in the sump, the annual rates of emergent-vegetation 
Table 4. Area of land in different land-use categories in the Tule Lake National Wildlife Refuge, Oregon and California, 2003-2005.

[Some small, noncontiguous units of refuge property, Area J unit, and narrow upland units located along the borders of Sumps 1A, 1B, and 2 are not included. Source: Tim Mayer, U.S. Fish and Wildlife Service, Portland, Oregon, written commun., 2005]

\begin{tabular}{|c|c|c|c|c|c|}
\hline \multirow[b]{2}{*}{ Land-Use Category } & \multicolumn{5}{|c|}{ Area (acres) } \\
\hline & $\underset{1 A}{\text { Sump }}$ & $\begin{array}{c}\text { Sump } \\
\text { 1B }\end{array}$ & $\begin{array}{c}\text { Sump } \\
2\end{array}$ & $\begin{array}{c}\text { Sump } \\
\mathbf{3}\end{array}$ & Total \\
\hline \multicolumn{6}{|c|}{2003 Habitat Plan } \\
\hline Grain & 0 & 0 & 6,131 & 10,903 & 17,034 \\
\hline Seasonal wetland & 0 & 3,326 & 278 & 643 & 4,246 \\
\hline Emergent vegetation & 929 & 0 & 0 & 381 & 1,311 \\
\hline Open water & 8,363 & 0 & 0 & 381 & 8,744 \\
\hline Total & 9,292 & 3,326 & 6,409 & 12,309 & 31,335 \\
\hline \multicolumn{6}{|c|}{2004 Habitat Plan } \\
\hline Grain & 0 & 0 & 6,409 & 10,885 & 17,294 \\
\hline Seasonal wetland & 0 & 0 & 0 & 528 & 528 \\
\hline Emergent vegetation & 929 & 831 & 0 & 435 & 2,196 \\
\hline Open water & 8,363 & 2,494 & 0 & 435 & 11,292 \\
\hline Total & 9,292 & 3,326 & 6,409 & 12,284 & 31,310 \\
\hline \multicolumn{6}{|c|}{2005 Habitat Plan } \\
\hline Grain & 0 & 0 & 6,409 & 10,589 & 16,998 \\
\hline Seasonal wetland & 0 & 0 & 0 & 267 & 267 \\
\hline Emergent vegetation & 929 & 832 & 0 & 751 & 2,512 \\
\hline Open water & 8,363 & 2,495 & 0 & 751 & 11,608 \\
\hline Total & 9,292 & 3,326 & 6,409 & 12,358 & 31,385 \\
\hline
\end{tabular}

evapotranspiration (2.63 ft) and open-water evaporation (4.07 $\mathrm{ft}$ ) were applied to their associated portions of the sump for each year. The 3-year average water use in the sump was approximately 36,500 acre-ft (table 5).

All of Sump 1B was managed as permanent, openwater wetland in 2003. However, in 2004-2005, the sump was managed as both a seasonal and permanent wetland. Appropriate rates shown in table 1 were used to compute water use for each year. To estimate 2004-2005 water use, the annual emergent-vegetation-evapotranspiration rate $(2.63 \mathrm{ft})$ was applied to 25 percent of the sump and the annual openwater evaporation rate $(4.07 \mathrm{ft})$ was applied to the other 75 percent of the area. The 3-year mean annual water use in Sump 1B was approximately 11,400 acre-ft.

The 3-year mean annual water use in Sumps 2 and 3 was approximately 16,000 and 31,900 acre-ft, respectively. Most of Sumps 2 and 3 are managed for grain. Water use in these units was based on the annual evapotranspiration rate of $2.5 \mathrm{ft}$. However, Sumps 2 and 3 also contain seasonal and permanent
Table 5. Estimated water use in the Tule Lake National Wildlife Refuge, Oregon and California, 2003-2005.

[Water-use categories are based on annual rates shown in table 1; "Adjusted water delivery" is the estimated water delivery plus additional water for salinity flushing. Source: Tim Mayer, U.S. Fish and Wildlife Service, Portland, Oregon, written commun., 2005]

\begin{tabular}{|c|c|c|c|c|c|}
\hline \multirow[b]{2}{*}{ Land-Use Category } & \multicolumn{5}{|c|}{ Water use (acre-feet) } \\
\hline & $\underset{1 A}{\text { Sump }}$ & $\underset{1 B}{\text { Sump }}$ & $\begin{array}{c}\text { Sump } \\
2\end{array}$ & $\begin{array}{c}\text { Sump } \\
3\end{array}$ & Total \\
\hline \multicolumn{6}{|c|}{2003 Habitat Plan } \\
\hline Grain & 0 & 0 & 15,328 & 27,257 & 42,585 \\
\hline Seasonal wetland & 0 & 9,644 & 805 & 1,865 & 12,314 \\
\hline Emergent vegetation & 2,444 & 0 & 0 & 1,003 & 3,447 \\
\hline Open water & 34,037 & 0 & 0 & 1,552 & 35,589 \\
\hline Total water use & 36,480 & 9,644 & 16,132 & 31,678 & 93,935 \\
\hline Precipitation & $-8,069$ & $-2,888$ & $-5,565$ & $-10,688$ & $-27,209$ \\
\hline Water delivery & 28,412 & 6,757 & 10,568 & 20,990 & 66,726 \\
\hline $\begin{array}{l}\text { Adjusted water } \\
\text { delivery }\end{array}$ & 34,094 & 8,108 & 12,681 & 25,188 & 80,071 \\
\hline \multicolumn{6}{|c|}{2004 Habitat Plan } \\
\hline Grain & 0 & 0 & 16,022 & 27,275 & 43,297 \\
\hline Seasonal wetland & 0 & 0 & 0 & 1,533 & 1,533 \\
\hline Emergent vegetation & 2,444 & 2,187 & 0 & 1,144 & 5,775 \\
\hline Open water & 34,037 & 10,152 & 0 & 1,771 & 45,959 \\
\hline Total water use & 36,480 & 12,338 & 16,022 & 31,723 & 96,563 \\
\hline Precipitation & $-5,722$ & $-2,048$ & $-3,947$ & $-7,565$ & $-19,282$ \\
\hline Water delivery & 30,758 & 10,290 & 12,075 & 24,158 & 77,281 \\
\hline $\begin{array}{l}\text { Adjusted water } \\
\text { delivery }\end{array}$ & 36,910 & 12,348 & 14,490 & 28,990 & 92,738 \\
\hline \multicolumn{6}{|c|}{2005 Habitat Plan } \\
\hline Grain & 0 & 0 & 16,023 & 26,472 & 42,494 \\
\hline Seasonal wetland & 0 & 0 & 0 & 774 & 774 \\
\hline Emergent vegetation & 2,444 & 2,187 & 0 & 1,975 & 6,606 \\
\hline Open water & 34,037 & 10,153 & 0 & 3,057 & 47,246 \\
\hline Total water use & 36,480 & 12,339 & 16,023 & 32,278 & 97,120 \\
\hline Precipitation & $-10,121$ & $-3,623$ & $-6,980$ & $-13,460$ & $-34,183$ \\
\hline Water delivery & 26,360 & 8,717 & 9,042 & 18,818 & 62,937 \\
\hline $\begin{array}{l}\text { Adjusted water } \\
\text { delivery }\end{array}$ & 31,632 & 10,460 & 10,850 & 22,582 & 75,524 \\
\hline \multicolumn{6}{|c|}{ 2003-2005 Averages } \\
\hline Total water use & 36,480 & 11,441 & 16,059 & 31,893 & 95,873 \\
\hline $\begin{array}{l}\text { Adjusted water } \\
\text { delivery }\end{array}$ & 34,212 & 10,306 & 12,674 & 25,586 & 82,778 \\
\hline
\end{tabular}

wetlands, which change in area from year to year. Water use for those units was computed using the annual rates shown in table 1. Because the permanent wetland units in these sumps are much shallower than Sump 1A, a 1:1 ratio of emergentvegetation and open-water rates was applied to these units. 
The 3-year mean annual water-use volume for the entire refuge, including seasonal-wetland, open-water, and agricultural water use, was approximately 95,900 acre-ft (table 5). To estimate needed annual water deliveries for the refuge, estimated annual water use was reduced by annual precipitation. For water years 2003, 2004, and 2005, annual precipitation, measured at the nearby Tule Lake Agricultural Station in Tule Lake, California, was 10.4, 7.4, and 13.1 in., respectively (California Department of Water Resources, 2005). After subtracting precipitation from the water-use volumes, 20 percent was added to account for salinity flushing. The estimated needed water deliveries for each of the sumps are shown in table 5. The needed mean annual water delivery for the entire refuge for the 3-year period was estimated as about 82,800 acre-ft.

\section{Uncertainty in Open-Water Evaporation and Evapotranspiration Estimates}

Various factors contribute uncertainty in estimating wateruse and water-delivery needs based on open-water evaporation and evapotranspiration estimates. The accuracy of the evaporation and evapotranspiration estimates described earlier could be improved if pan evaporation data were collected at both refuges. The rates presented herein are based on average conditions. In reality, evaporation and evapotranspiration rates vary from year to year. The rates presented in this report also are based on evaporation and air temperature data that were not collected in recent years nor are local to the refuges. The open-water evaporation rate is based on pan evaporation data collected from 1956 to 1981 . Wind conditions also significantly affect evaporation and evapotranspiration rates. As a result, evaporation and evapotranspiration rates can vary among different locations within the two refuges because of geographic variation in wind conditions. Overall accuracy of the evapotranspiration estimates also could be improved with specific evapotranspiration rates for different types of grain vegetation in the refuge. However, acquiring more specific crop information was not possible within the scope and timeline of this project.

Adjusting needed water deliveries to account for salinity flushing over time introduces additional uncertainty. The salinity factor used in the study was based on measured specific conductance data collected at various locations within and surrounding the refuges. However, specific conductance levels vary with location and with seasonality.

\section{Water-Use Estimates Based on Inflows and Outflows}

Measured inflows to and outflows from the refuges were used to make a separate estimate of refuge water use for comparison with those based on evapotranspiration estimates. Project inflows include all water originating from the Project that is drained or pumped into both the Tule Lake and Lower Klamath refuges.

\section{Lower Klamath Refuge}

Mean annual Project inflows to and outflows from the Lower Klamath refuge for 2003-2005 are based on measured flow data collected at D Pumping Plant, Ady Canal at State Line Road, and the Klamath Straits Drain at State Line Road. For water years 2003-2005, the combined mean annual inflow into the refuge through D Pumping Plant and from the Ady Canal was approximately 89,000 acre-ft, and mean annual outflow through the Klamath Straits Drain was approximately 15,300 acre-ft (table 6). The resulting net inflow was approximately 73,700 acre-ft. This amount is comparable to the estimated needed water delivery of approximately 77,600 acre-ft for the non-Area K refuge units located south of State Line Road that are irrigated by Project water.

Mean annual net inflow to the Lower Klamath refuge was approximately 49,800 acre-ft for 1962-2005 in contrast to about 73,700 acre-ft for 2003-2005 (table 7). Although mean April-September net inflows for 1962-2005 and 2003-2005 have remained fairly constant, mean October-March net inflow has increased considerably for 2003-2005. Increased flow deliveries during the autumn and winter since the mid1980s reflect a significant change in refuge management, as more units have been managed as seasonal wetlands than in the 1960s and 1970s (fig. 3). In water years 1963, 1973, and 1984, there was no net inflow during the winter months of October-March, because more water was draining out of the refuge than was being pumped in. In the summer of water year 1965, there also was no net inflow of water to the refuge. Because of severe flooding in the previous October, the refuge already had saturated conditions and less water delivery was required.

Changes in the management of both refuges also can be observed in figure 4, which are graphs of monthly flows from 1961 through 2005 for Ady Canal, Klamath Straits Drain, 
Table 6. Estimated 2003-2005 mean annual inflows to and outflows from the Lower Klamath and Tule Lake National Wildlife Refuges, Oregon and California.

[Lower Klamath National Wildlife Refuge: Average of 2003-2005 annual flows (Source: Jon Hicks, Bureau of Reclamation, Klamath Falls, Oregon, written commun., 2005). Tule Lake National Wildlife Refuge: Flows based on 1989-1999 period except for D Pumping Plant]

\begin{tabular}{lc}
\hline \multicolumn{2}{c}{ Lower Klamath National Wildlife Refuge } \\
\hline Inflow (acre-feet per year) & 59,606 \\
$\quad$ D Pumping Plant & 29,434 \\
Ady Canal & $-15,338$ \\
Outflow (acre-feet per year) & \\
$\quad$ Klamath Straits Drain & 73,703 \\
Comparison of net inflow to water delivery & 77,643 \\
$\quad$ Net inflow & \\
Water delivery ${ }^{1}$ & \\
\hline & \\
\hline & Tule Lake National Wildlife Refuge \\
\hline Inflow (acre-feet per year) & 46,140 \\
N Canal & 24,600 \\
Lost River & 81,250 \\
Sump 1A and 1B inflows & 19,000 \\
Net ground-water inflow & \\
Outflow (acre-feet per year) & $-59,606$ \\
D Pumping Plant outflow & $-35,300$ \\
N Canal & \\
Comparison of net inflow to water delivery & 76,084 \\
Net inflow & 82,778 \\
Water delivery ${ }^{2}$ & \\
\hline
\end{tabular}

${ }^{1}$ Estimated needed water delivery for refuge areas south of State Line Road, table 3.

${ }^{2}$ Estimated needed water delivery for entire refuge, table 5.

Table 7. Mean net inflows to the Lower Klamath National Wildlife Refuge, Oregon and California, 1962-2005 and 2003-2005.

[Calculated as D Pumping Plant and Ady Canal flows minus Klamath Straits and 25 percent of $\mathrm{P}$ Canal flows]

\begin{tabular}{lcc}
\hline Mean net inflows (acre-feet per year) & 1962-2005 & 2003-2005 \\
\hline Annual & 49,819 & 73,703 \\
October through March & 19,583 & 40,458 \\
April through September & 30,236 & 33,245 \\
\hline
\end{tabular}

and D Pumping Plant. Figure $4 A$ shows an increase in flow deliveries to the Lower Klamath refuge during the fall and winter since the late 1980s. During this period, flows also decreased in the Klamath Straits Drain (fig. $4 B$ ). Both these trends are a reflection of the increase in the number of units that were flooded in the autumn and winter and managed as seasonal wetlands. Beginning in the early 1990s, more water was held in Sumps 1A and 1B to maintain a minimum elevation under ESA guidelines for sucker habitat protection. This change in management is seen in figure $4 C$. Significantly less water was pumped out of the sumps in the 1990s than during October-December in the three earlier decades. It also is possible to discern historical wet and dry periods from figures $4 A-4 C$. During wet years, such as 1965, 1984, and the late 1990s, there is some correspondence between the D Pumping Plant and Klamath Straits Drain flows. More water is pumped through the D Pumping Plant to drain the Tule Lake sumps, and much of that water then passes through the Lower Klamath refuge. In dry years, such as 1981 and the early 1990s, more water deliveries were made through the Ady Canal (fig. 4A).

\section{Tule Lake Refuge}

Most of the Project water is delivered to the Tule Lake refuge via the $\mathrm{N}$ Canal, Lost River, and numerous pumped inflows. Although there are no permanent flow gages on these canals or on the Lost River at locations near the refuge boundaries, some estimates of flow into the refuge by way of these waterways can be derived from a USFWS surfacewater budget analysis of the refuge sumps. Mean annual inflows from the N Canal, Lost River, and miscellaneous pumped inflows were estimated to be approximately 46,100, 24,600, and 81,300 acre-ft, respectively (table 6). The USFWS analysis of Sump 1A and 1B had a deficit between surfacewater inflow and outflow of approximately 30,300 acre-ft/yr. This amount includes surface-water-flow measurement error as well as probable unmeasured ground-water flow. Because there is an eastward ground-water head gradient along the western margin of the refuge, it is likely that there is some seepage entering Sump 1A and 1B from the Lower Klamath refuge and BOR Project lands to the west. The same USFWS analysis also showed a surplus between surface-water inflow 
and outflow from Sump 3 of approximately 11,300 acre-ft/yr. Ground-water flow from the southern part of the Tule Lake subbasin is consistent with hydraulic head data as well as historical accounts. The surface-water balance for the entire refuge had a deficit of approximately 19,000 acre-ft/yr. This amount includes both surface-water-flow measurement error and probable unmeasured ground-water flow. As stated earlier, the proportion attributed to surface-water measurement error versus the proportion attributed to ground-water flow is unknown. Most surface-water outflow from the refuge is through the D Pumping Plant and the N Canal. Estimated annual flow through the D Pumping Plant and the N Canal was approximately 59,600 and 35,300 acre-ft, respectively.
Subtracting the sum of estimated surface-water outflows from the sum of estimated surface-water inflows and net groundwater inflow results in an annual net surface-water inflow to the refuge of approximately 76,100 acre-ft. This volume is consistent with the estimated needed water delivery total of 82,800 acre-ft shown in table 5 on the basis of open-water evaporation and evapotranspiration estimates. However, both methods of estimating water use, using evaporation and evapotranspiration estimates or inflows and outflows, have a wide range of uncertainty. Evaporation and evapotranspiration rates represent only average conditions, whereas much of the Tule Lake refuge inflow and outflow data were based on miscellaneous (rather than continuously monitored) flow measurements.

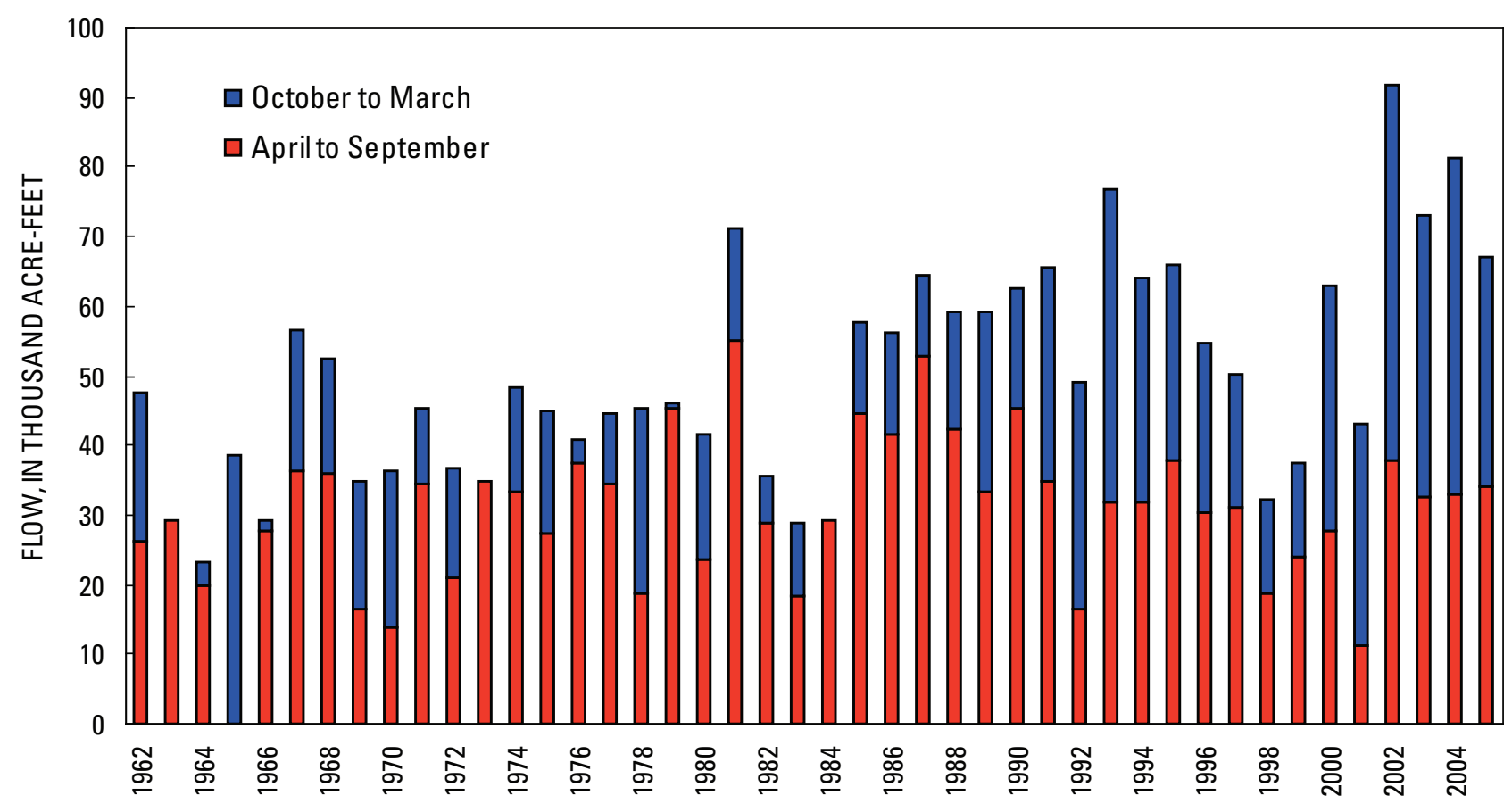

Figure 3. Lower Klamath National Wildlife Refuge net inflow, Oregon and California, 1962-2005. Calculated as D Pumping Plant and Ady Canal flows minus Klamath Straits flows. 


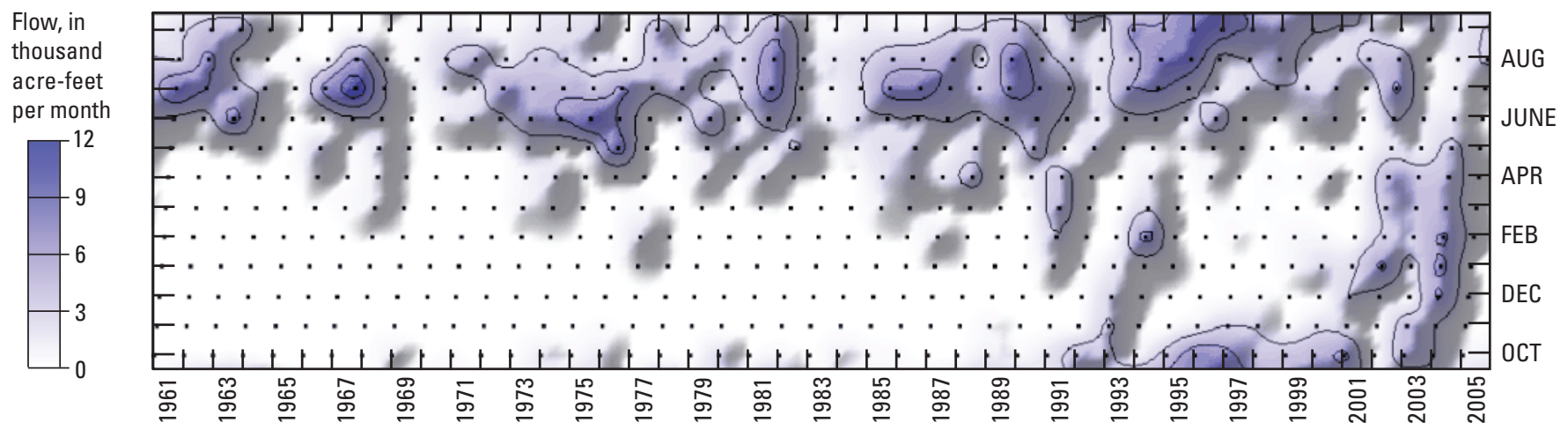

A. Ady Canal at State Line Road, water years 1961-2005

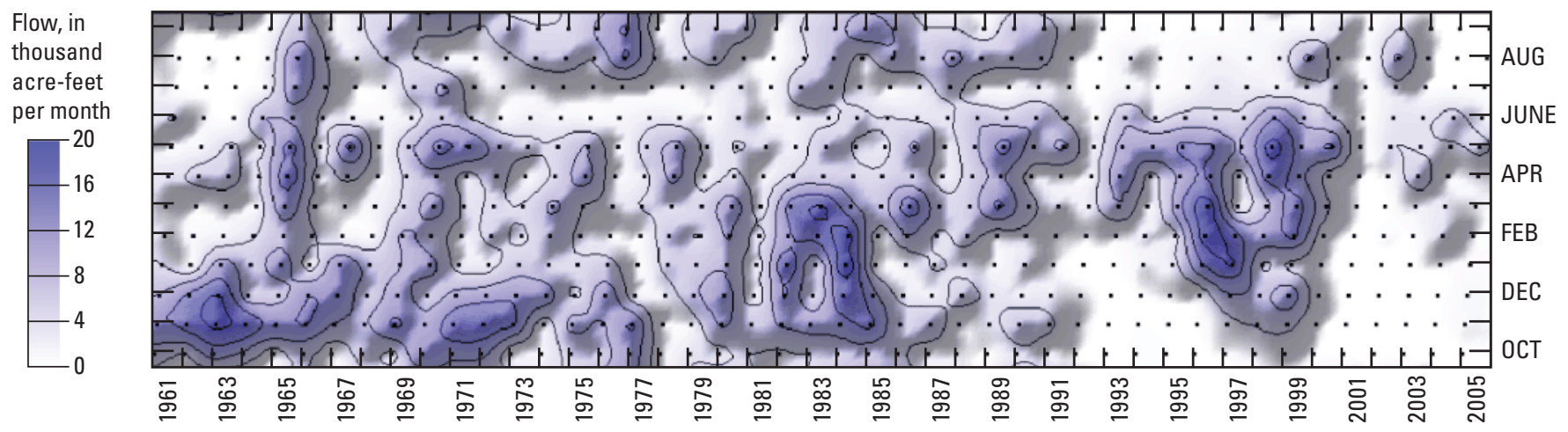

B. Klamath Straits Drain at State Line Road, water years 1961-2005

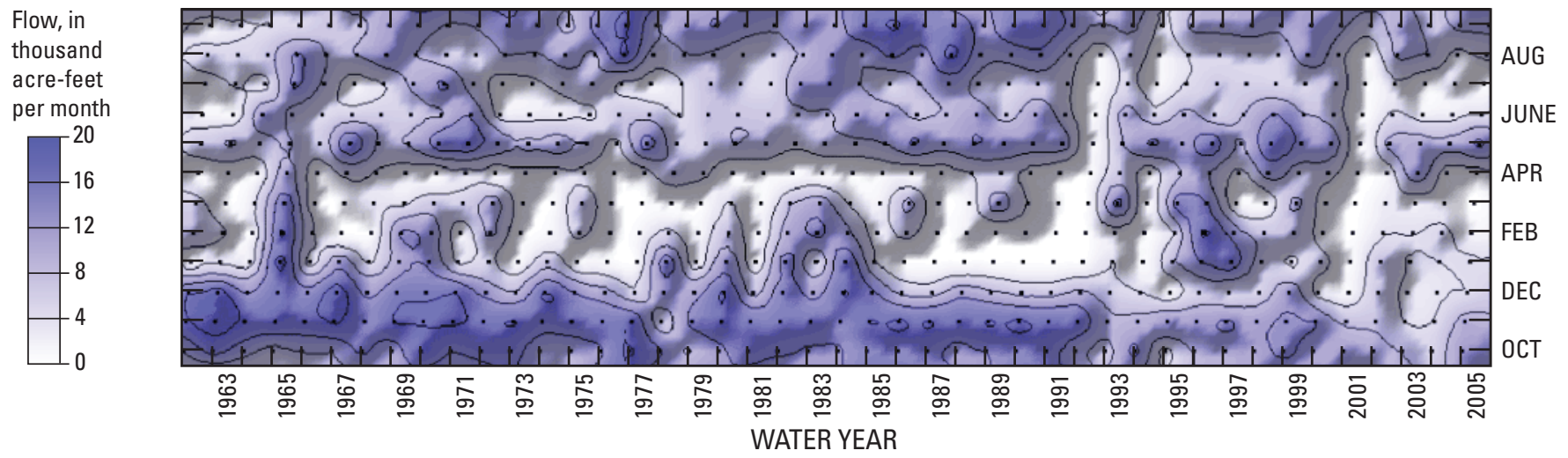

C. D Pumping Plant, water years 1962-2005

Figure 4. Monthly flows for Ady Canal, Klamath Straits Drain, and D Pumping Plant, Lower Klamath and Tule Lake National Wildlife Refuges, Oregon and California, 1961 through 2005. 


\section{Refuge Water Budgets}

Water budgets that approximate 2003-2005 conditions as much as possible for both refuges shown in figure 5 are based on the combination of annual water-use estimation using acreages and open-water evaporation and evapotranspiration estimates (tables 1-5) and measured inflows and outflows to and from the refuges (table 6). The percentages shown in figure 5 pertain to the budgets for each refuge separately; that is, they are relative to the total for each refuge. For example, 21 percent of all water entering the Lower Klamath refuge is from precipitation and only 13 percent of all water entering the Tule Lake refuge is from precipitation. However, this does not mean that more precipitation falls on the Lower Klamath refuge than the Tule Lake refuge; it simply indicates that precipitation accounts for more of the water entering the Lower Klamath refuge than the Tule Lake refuge. The 2003-2005 mean annual precipitation for both refuges is actually similar. Likewise, evapotranspiration loss for the Lower Klamath refuge constituted a much greater percentage of the water leaving the refuge compared with the Tule Lake refuge. However, the actual evapotranspiration rates were the same for both refuges.
Gaged flows that were used in the budget calculations for figure 5, such as those for D Pumping Plant, Ady Canal, and the Klamath Straits Drain, were from the 2003-2005 period. However, inflows and outflows for the Tule Lake refuge were derived from a USFWS water budget analysis of the refuge (Tim Mayer, U.S. Fish and Wildlife Service, Portland, Oregon, written commun., 2005). More recent flow data for those locations were either unavailable or not easily obtainable.

Ground-water fluxes in and out of the refuges are shown with dashed lines because they are unknown and cannot be discriminated from measurement error. The value shown for ground-water inflows and outflows and measurement error in the Tule Lake refuge were derived from residual terms in the USFWS water budget analysis (Tim Mayer, U.S. Fish and Wildlife Service, Portland, Oregon, written commun., 2005). Natural runoff into the Lower Klamath refuge from Sheepy, Cottonwood, and Willow Creeks were based on estimates from Wood (1960).

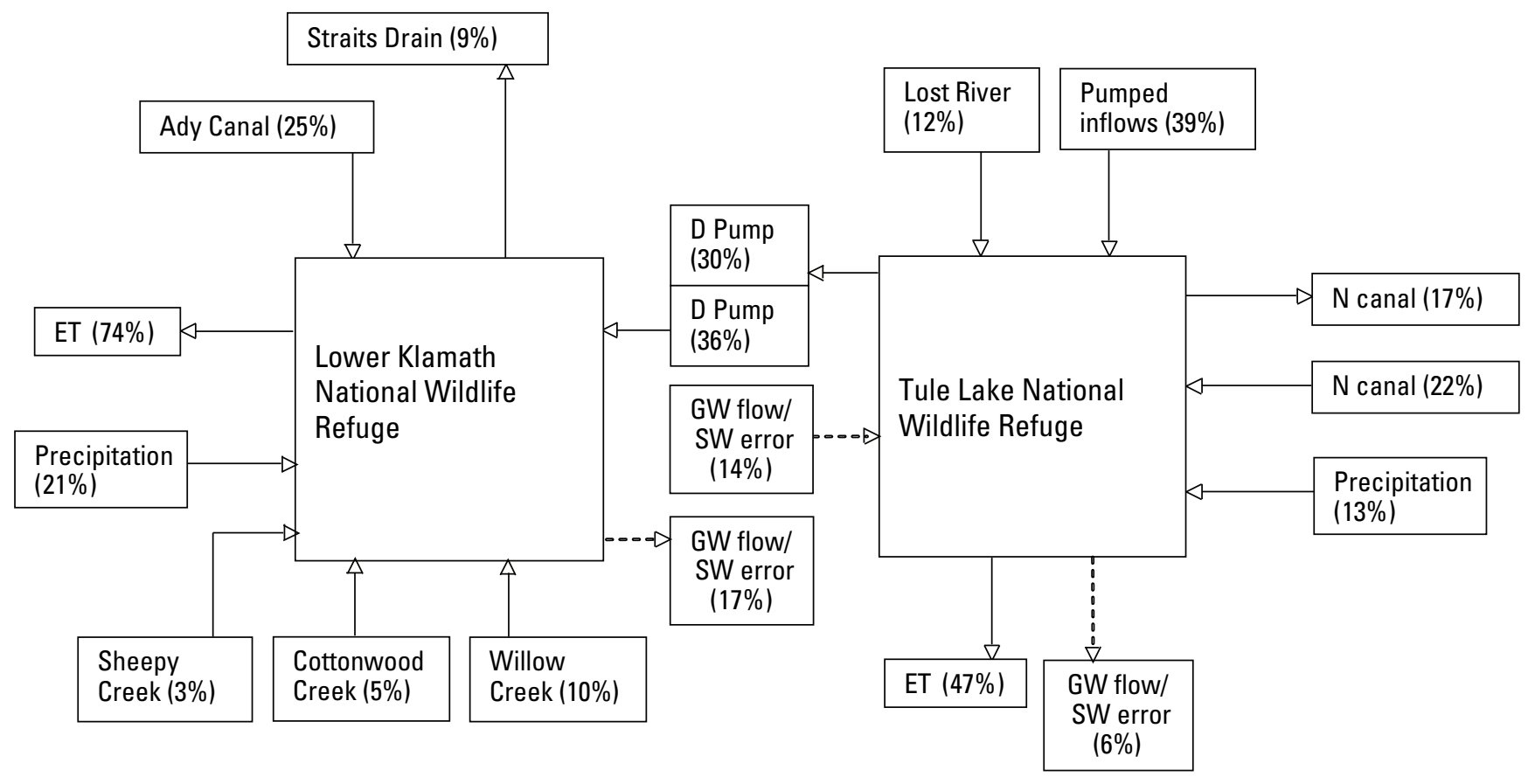

Figure 5. Water budget, derived from an approximation of 2003-2005 conditions, for Lower Klamath and Tule Lake National Wildlife Refuges, Oregon and California.

Percentages pertain to either inflows or outflows for each refuge. ET=combined open-water evaporation and evapotranspiration;

$\mathrm{GW}=$ ground water, and SW=surface water. Ground-water flow through the refuges as shown in the diagram is consistent with measured groundwater elevation data in the region. However, percentages assigned to the ground-water fluxes are based on residuals from surface-water budget analyses. The residuals are a result of both probable unmeasured lground-water flow and surface-water flow measurement error. 


\section{Flow Data Quality}

The main flow channels entering and leaving the refuges that have been continuously monitored are the Ady Canal at State Line Road, Klamath Straits Drain at State Line Road, and D Pumping Plant on the edge of Tule Lake Sump 1A. Monthly records for all three sites go back as far as 1962 in the BOR hydrologic database. The accuracy and quality of the measurements and the records were assessed because of their importance in determining refuge water use.

\section{Accuracy of the Records}

Flow data collection at these three sites is serviced by the BOR, USFWS, Klamath Drainage District, and TID. Overall flow-record documentation for these sites is limited, as the records have not been compiled, reviewed, and published on an annual basis. It was not possible to document how every flow record value was computed. Annual station analyses for the sites were nonexistent. (Recently, however, the USFWS has improved flow-measurement accuracy at the Ady Canal site.) Daily values at all three sites were not computed from unit (hourly) values. Although continuous strip charts were used at the Klamath Straits Drain site to estimate head differences, only a single head difference value was taken (manually) from the charts for each day.

The rating the USGS uses to describe the accuracy of an annual streamflow record depends on (1) the stability of the stage-discharge relation or, if the control is unstable, the frequency of discharge measurements and (2) the accuracy of measurements of stage, measurements of discharge, and interpretation of records (Herrett and others, 2004). An "Excellent" rating indicates that about 95 percent of the daily discharges are within 5 percent of the true value. A "good" and "fair" rating indicates that about 95 percent of the daily discharges are within 10 and 15 percent of the true value, respectively. Records that are considered to be less accurate are rated "poor." Different accuracies may be assigned to different parts of a record. Because the USGS flow-record rating is applied to a record on an annual basis, it can be changed from year to year. For this assessment, the ratings, presented in the following sections for each of the flow gages, also were based on current conditions of the instrumentation, record compilation methods, and the existence of documentation regarding how every daily value was computed. Accuracy ratings for the three sites are shown in table 8. In addition to USGS ratings, accuracy ratings that were assessed by the California Polytechnic State University Irrigation Training and Research Center are also shown (Burt and Freeman, 2003).
Table 8. Accuracy ratings for Ady Canal, Klamath Straits Drain, and D Pumping Plant flow records, Oregon and California.

[Ratings: USGS, Based on water year 2005 record; Cal Poly, Based on water year 1999 and 2000 records. Both ratings are defined as the percent error within true flow of 95 percent of daily flows. Abbreviations: USGS, U.S. Geological Survey; Cal Poly, California Polytechnic State University Irrigation Training and Research Center; na, not available. >, greater than]

\begin{tabular}{|c|c|c|c|}
\hline \multicolumn{2}{|c|}{ Diversion flow gages } & \multicolumn{2}{|c|}{ Ratings } \\
\hline Canal/River & Location & $\begin{array}{c}\text { USGS } \\
\text { (percent) }\end{array}$ & $\begin{array}{c}\text { Cal Poly } \\
\text { (percent) }\end{array}$ \\
\hline Ady Canal & $\begin{array}{l}\text { State Line Road, Oregon- } \\
\text { California }\end{array}$ & $>15$ & 35 \\
\hline $\begin{array}{l}\text { Klamath Straits } \\
\text { Drain }\end{array}$ & $\begin{array}{l}\text { State Line Road, Oregon- } \\
\text { California }\end{array}$ & $>15$ & na \\
\hline $\begin{array}{l}\text { D Pumping } \\
\text { Plant }\end{array}$ & $\begin{array}{l}\text { Sump 1A, Tule Lake } \\
\text { National Wildlife Refuge, } \\
\text { California }\end{array}$ & $>15$ & 25 \\
\hline
\end{tabular}

\section{Ady Canal at State Line Road}

The Ady Canal structure at State Line Road consists of four Waterman 48" circular canal gates. The two east gates divert water to Unit 2 in the refuge and generally are open. The two west gates divert water through pipes to Unit 5a and the Sheepy West unit, and generally are closed from April-September. Upstream and downstream water levels are measured by two staff plates. The plates generally are read on a weekly basis, or whenever the gate openings are changed by USFWS or BOR technicians. Flows are computed using a modified version of the Waterman gate flow equation. Input variables to the equation are the gate opening and the head difference between the upstream and downstream water levels.

In 2000, the USFWS made a series of check

measurements at the site on the downstream side of State Line Road. (Check measurements are direct measurements of flow that are used to verify the accuracy of flow estimates made with the use of rating curves or other indirect methods.) The USFWS made an additional check measurement on September 12, 2005. Measured flow was $115 \mathrm{ft}^{3} / \mathrm{s}$. With the measurements, it was possible to construct a relation between the flow measurements and estimated flows using a canal gate equation (Tim Mayer, U.S. Fish and Wildlife Service, Portland, Oregon, written commun., 2005).

The USGS made a check measurement at this site on August 24, 2005, on the south side of State Line Road using an acoustic Doppler current profiler. Measured flow was $123 \mathrm{ft}^{3} / \mathrm{s}$. The flow computed from the USFWS canal gate equation using a gate opening of $18 \mathrm{in}$. and head difference of $3.4 \mathrm{ft}$ at the time of the measurement was $135 \mathrm{ft}^{3} / \mathrm{s}$, which is an overestimation of approximately 10 percent. 
To rate the current flow record for the Ady Canal site, various factors were considered. The most critical factor is that there is no continuously operating instrumentation at this site. Data are acquired by reading staff plates. However, in examining records in the BOR office in Klamath Falls, there was no evidence that the staff plates and gate openings were read and recorded on a daily basis; nonetheless, individual daily flow computations using the equation were still made. This site also did not have ideal cross-section locations that are needed to make accurate check measurements. Because of these factors, this flow record was rated as "poor." In other words, 95 percent of the daily flows could be in error by more than 15 percent.

\section{Klamath Straits Drain at State Line Road}

The Klamath Straits Drain structure at State Line Road consists of three canal gates. Similar to the Ady Canal gates, flow is computed at this site using the gate openings and the upstream and downstream head difference. Unlike the Ady Canal site, there are two Stevens drum-type stage recorders mounted on stilling wells upstream and downstream of the gates. Continuous recorders make it possible to compute daily flows with more reliability. At the time of this study, flows at this location were close to zero, and it was not possible for the USGS to make a check measurement. It could not be determined when the last check measurement was made at this site and by what agency.

On the basis of most factors, this flow record could have been rated as "fair," in which case 95 percent of the daily flows would have been defined as being within 10 to 15 percent of true flow. However, the flow record for this site did not have adequate documentation of how each daily flow value was determined. For this reason, the flow record was rated as "poor," indicating that 95 percent of the daily flow values could have been in error by more than 15 percent.

\section{Pumping Plant}

The D Pumping Plant has five pumps. Pumps 1, 2, and 3 are rated by the manufacturer as having a pumping capacity of 160 acre-ft/d $\left(80.7 \mathrm{ft}^{3} / \mathrm{s}\right)$, and pumps 4 and 5 have a pumping capacity of 142 acre-ft/d $\left(71.6 \mathrm{ft}^{3} / \mathrm{s}\right.$ ) (Ron Fensler, Tulelake Irrigation District, Tulelake, California, oral commun., 2005). Although the plant was constructed in the 1940s, most of the pumps have been replaced or retooled since that time. Daily flow estimates are made by keeping a daily record of the number of pumps in operation and their duration of operation.

On August 3, 2005, the USGS made a flowmeter check measurement of the D Pumping Plant by measuring flow in the P Canal at Doris Brownell Road. Measured flow was 82 $\mathrm{ft}^{3} / \mathrm{s}$. However, upstream of the measurement, approximately
$1,800 \mathrm{gal} / \mathrm{min}$ (about $4 \mathrm{ft}^{3} / \mathrm{s}$ ) was being pumped out of the canal to a farm field. Without that withdrawal, the flow would have been approximately $86 \mathrm{ft}^{3} / \mathrm{s}$. The flow measurement was rated "fair," which for individual flow measurements (unlike annual streamflow records discussed above) means that the measurement could have been off by 8 percent of true flow. Actual flow, then, might have been within the range of 75-89 $\mathrm{ft}^{3} / \mathrm{s}$. At the time of the measurement, TID was operating one pump continuously for several days. The USFWS also made check measurement at the same location on the P Canal on November 1, 2000, and measured $218 \mathrm{ft}^{3} / \mathrm{s}$. At the time of that measurement, three pumps were operating. BOR records for that date reported a flow of 436 acre- $\mathrm{ft} / \mathrm{d}\left(220 \mathrm{ft}^{3} / \mathrm{s}\right)$ at D Pumping Plant.

Similar to the Klamath Straits Drain flow record, this flow record also could have been rated "fair." However, the flow record for this site did not have adequate documentation of how each daily flow value was determined. For this reason, the flow record was rated "poor," indicating that 95 percent of the daily flows could be in error by more than 15 percent.

\section{Suggested Improvements to the Flow-Data- Collection Network}

In recent years, the need for more accurate flow measurements of water entering and leaving both the Lower Klamath and Tule Lake refuges has become apparent. Following are improvements that could be made to the data-collection network to increase the accuracy of flow measurements. The USGS is aware that some of these improvements already are planned through current collaboration between the BOR and the Irrigation Training and Research Center of California Polytechnic State University.

\section{Coordination}

Data consistency, management, storage, and retrievals would be improved if all refuge boundary flow data collection efforts were performed by a single agency, either the BOR, USFWS, or USGS. All flow records, both past and future, would be archived by and stored at the offices of a single agency.

\section{Documentation}

Proper documentation of all aspects of flow-data collection is essential for maintaining a high-quality datacollection program. It requires the maintenance of an archive for each data-collection site that includes hourly stage values, rating curves, check measurements, stage shifts, rating shifts, and stage measurements, which can be used to recreate any or all of the published daily flow record if necessary. 


\section{Equipment Modernization}

Digital data loggers are more accurate and reliable than strip-chart stage recorders, which were originally developed in the 1930s. The Klamath refuge data collection program would be much enhanced by the installation of digital data loggers with real-time telemetry at the Klamath Straits Drain flow site, Ady Canal at State Line Road site, the D Pumping Plant, and possible new sites.

\section{Check Measurements}

Check measurements help verify the accuracy of the flow record at data-collection sites. Depending on the stability of a stream's channel bed, USGS protocol stipulates that a check measurement be made at each site generally every 3 months. Check measurements made with the same frequency at refuge boundary flow sites would provide a degree of confidence in the quality of the data that would not be possible without such measurements.

\section{Additional Flow Sites}

The main flow channels near or at the boundary of the Lower Klamath refuge (Ady Canal, D Pumping Plant, and Klamath Straits Drain) already are gaged. However, periodic flow measurements at Sheepy, Cottonwood, and Willow Creeks would increase the accuracy of inflow estimates because the cumulative flow of these streams, approximately 14 percent of inflow to the refuge, is significant.

To further improve the measurement of flow into the Tule Lake refuge, the BOR and/or the USFWS could install a streamflow gage on the Lost River near the entrance of the refuge, if it is feasible. Another possible site for a gage would be at the main points where Project water enters the $\mathrm{N}$ Canal. Most of the N Canal water is used to service Sump 3. However, unlike the Lower Klamath refuge, flow comes into the Tule Lake refuge at many locations. Flows at many of those locations may still have to be estimated, because establishing flow gages would not be practical.

\section{Summary and Conclusions}

Demand for water in the semiarid upper Klamath Basin of southern Oregon and northern California has increased in recent years, resulting in the need to better quantify water availability and use in and around the Bureau of Reclamation Klamath Project. Most of the water entering the Lower Klamath and Tule Lake National Wildlife Refuges originates from the Project. In 2005 the Bureau of Reclamation asked the U.S. Geological Survey Oregon Water Science Center to evaluate and better quantify water use and flow data to and from the refuges.

Located south of the Project and mostly in California, the Lower Klamath and Tule Lake refuges encompass approximately 46,700 and 39,100 acres, respectively. Roughly one-third of the combined refuge surface areas are leased to farmers for cereal grain and alfalfa production. Since the early 1900s, surface-water flow to and from the refuges has developed into a highly regulated system.

The Lower Klamath refuge receives most of its water from the D Pumping Plant via a tunnel under Sheepy Ridge, Ady Canal, and precipitation. Additional, smaller quantities of water enter the refuge from springs that supply flow to Sheepy, Willow, and Cottonwood Creeks. Most of the water leaves the refuge through open-water evaporation, evapotranspiration from vegetated wetlands, and the Klamath Straits Drain. Water is pumped through the Klamath Straits Drain into the Klamath River.

Water enters the Tule Lake refuge from Project returnflow canals, the Lost River, the N Canal, precipitation, and ground-water seepage. Water leaves the refuge through the D Pumping Plant, open-water evaporation, evapotranspiration from vegetated wetlands, and ground-water seepage. The Tule Lake refuge is composed of four major sumps, which include Sumps 1A, 1B, 2, and 3. Sumps 1A and 1B usually are yearround open-water bodies, whereas Sumps 2 and 3 usually are leased for agriculture.

Annual water-use estimates for the refuges were computed using separate open-water evaporation and evapotranspiration rates and acreage for four land-use categories. On the basis of local climate data and data from previous studies, the estimated combined annual open-water evaporation and evapotranspiration rates for grain fields, seasonal wetlands, emergent vegetation wetlands, and openwater bodies were, for this study, 2.5, 2.9, 2.63, and $4.07 \mathrm{ft}$, respectively. Total water use was estimated as the sum of the products of each rate and the number of acres in its associated land-use category. Because the number of acres in each landuse category changes each year, total water use was computed separately for 2003, 2004, and 2005 and then averaged to approximate current conditions. Mean annual (2003-2005) water use for the Lower Klamath and Tule Lake and refuges was approximately 124,000 and 95,900 acre-ft, respectively. To estimate needed water deliveries for each refuge, annual precipitation for 2003, 2004, and 2005 was subtracted from the annual water use estimate for those years. Twenty percent of those totals was then added to the estimates to account for long-term salinity flushing over time. The 2003-2005 mean annual estimated needed water deliveries for the Lower Klamath and Tule Lake refuges were 107,000 and 82,800 acre-ft, respectively. 
Using estimated and measured surface-water inflows and outflows for 2003-2005, mean annual net inflow to the refuges was computed by subtracting outflows from inflows. Computed 2003-2005 mean annual net inflow for the Lower Klamath refuge was approximately 73,700 acre-ft. This volume was computed by subtracting flow at Klamath Straits Drain at State Line Road from the sum of D Pumping Plant and Ady Canal at State Line Road flows. However, that value can be compared only to estimated water use in refuge units located south of State Line Road served by Project water. The estimated needed water delivery for those units is approximately 77,600 acre-ft (in contrast to the estimated needed water delivery for the entire refuge of 107,000 acre-ft) and comparable to the mean annual net inflow estimate above. For the Tule Lake refuge, mean annual 2003-05 net inflow was approximately 76,100 acre-ft, which was comparable to the estimated annual needed water delivery of 82,800 acre-ft.

For 1962-2005, mean annual net inflow to the Lower Klamath refuge was approximately 49,800 acre-ft, about 23,900 acre-ft less than for 2003-2005. Although mean April-September net inflows for 1962-2005 and 2003-2005 have remained fairly constant, mean October-March net inflows were greater during 2003-2005 than during 19622005. Increased autumn and winter flow deliveries starting in the mid-1980s reflected a significant change in refuge management: More units currently are managed as seasonal wetlands than were in the 1960s and 1970s.

Flow records for the Ady Canal at State Line Road, Klamath Straits Drain at State Line Road, and D Pumping Plant were evaluated for their data quality. On the basis of USGS flow-record criteria, all three flow records were rated as "poor." By definition, 95 percent of the daily flows in a record having this rating could be in error by more than 15 percent.

Improvement in the streamflow-data collection network at refuge boundary locations can be achieved through (1) data collection by a single agency - the Bureau of Reclamation, U.S. Fish and Wildlife Service, or U.S. Geological Survey, (2) better data documentation and archiving, (3) equipment modernization, (4) more frequent check measurements, and (5) new flow-measurement locations near the boundaries of both refuges.

\section{Acknowledgments}

The authors thank Tim Mayer, U.S. Fish and Wildlife Service, Portland, Oregon; Dave Mauser, U.S. Fish and Wildlife Service, Tulelake, California; Jon Hicks, Bureau of Reclamation, Klamath Falls; John Rasmussen, formerly with the Bureau of Reclamation, Klamath Falls, Oregon; and Beau Freeman, Irrigation Training and Research Center, California Polytechnic State University, San Luis Obispo, California, for their assistance in this study.

\section{References Cited}

Bureau of Reclamation, 2004 [revised], Pacific Northwest Cooperative Agricultural Weather Network (AgriMet), http://www.usbr.gov/pn/agrimet/monthlyet.html, accessed on August 19, 2005.

Burt, C., and Freeman, B., 2003, Klamath Basin investigation-Hydrologic assessment of the upper Klamath Basin, Issues and opportunities, Draft report, May 2003: San Luis Obispo, California, Irrigation Training and Research Center, California Polytechnic State University, $274 \mathrm{p}$.

California Department of Water Resources, 2005, California Irrigation Management Information System (CIMIS): http://wwwcimis.water.ca.gov/cimis/data.jsp, accessed on September 12, 2005.

Dunne, T. and Leopold, L.B., 1978, Water in Environmental Planning: San Francisco, W. H. Freeman and Company, p. 101.

Gay, T.E., and Aune, Q.A., compilers, 1958, Geologic map of California-Alturas sheet, Olaf P. Jenkins edition: California Division of Mines and Geology, scale 1:250,000, 2 sheets.

Herrett, T.A., Hess, G.W., House, J.G., Ruppert, G.P., and Courts, M.L., 2004, Water Resources Data, Oregon, Water Year 2004: U.S. Geological Survey Water Data Report OR-04-1, $996 \mathrm{p}$.

MacCoy, D.E., 1994, Physical, chemical, and biological data for detailed study of irrigation drainage in the Klamath Basin, California and Oregon, 1990-92: U.S. Geological Survey Open-File Report 93-497, 168 p.

Mayer, T., and Thomasson, R., 2004, Fall water requirements for seasonal diked wetlands at Lower Klamath National Wildlife Refuge: Wetlands, v. 24, no. 1, p. 92-103.

Oregon Water Resources Department, 1971, Klamath Basin: Salem, Oregon, 288 p.

Rieck, H.J., Sarna-Wojcicki, A.M., Meyer, C.E., and Adam, D.P., 1992, Magnetostratigraphy and tephrochronology of an upper Pliocene to Holocene record in lake sediments at Tulelake, northern California: Geological Society of America Bulletin, v. 104, no. 4, p. 409-428.

U.S. Fish and Wildlife Service, 2005, Klamath Basin National Wildlife Refuges Complex: http://www.fws. gov/klamathbasinrefuges/history.html, accessed on October 13, 2005.

Wood, P.R., 1960, Geology and ground-water features of the Butte Valley region, Siskiyou County, California: U.S. Geological Survey Water-Supply Paper 1491, 150 p. 
Manuscript approved for publication, February 4, 2006

Prepared by the U.S. Geological Survey Publishing Network

Publishing Service Center, Tacoma, Washington Linda Rogers

Donita Parker

Bobbie Jo Richey

For more information concerning the research in this report, contact the Director, Oregon Water Science Center

10615 SE Cherry Blossom Drive

Portland, Oregon 97216

http://or.water.usgs.gov 
总

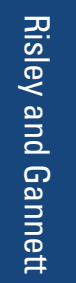

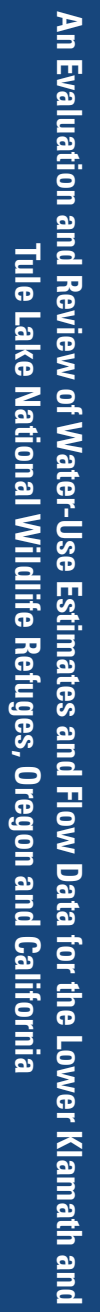

里

잉
잉 